Article

\title{
Targeting Glioblastoma via Selective Alteration of Mitochondrial Redox State
}

\author{
Akira Sumiyoshi ${ }^{1}$, Sayaka Shibata ${ }^{1}$, Zhivko Zhelev ${ }^{2,3}$, Thomas Miller ${ }^{4}$, Dessislava Lazarova ${ }^{5}$, Ichio Aoki ${ }^{1}$, \\ Takayuki Obata ${ }^{1}$, Tatsuya Higashi ${ }^{1}$ and Rumiana Bakalova ${ }^{1,5, *}$
}

1 Department of Molecular Imaging and Theranostics, National Institutes for Quantum and Radiological Science and Technology (QST), 4-9-1 Anagawa, Chiba 263-8555, Inage-ku, Japan; sumiyoshi.akira@qst.go.jp (A.S.); shibata.sayaka@qst.go.jp (S.S.); aoki.ichio@qst.go.jp (I.A.); obata.takayuki@qst.go.jp (T.O.); higashi.tatsuya@qst.go.jp (T.H.)

2 Faculty of Medicine, Trakia University, 6000 Stara Zagora, Bulgaria; zh_zhelev@yahoo.com

3 Institute of Biophysics and Biomedical Engineering, Bulgarian Academy of Sciences, 1000 Sofia, Bulgaria

4 IC-MedTech Corp., San Diego, CA 92101, USA; tmiller@ic-medtech.com

5 Faculty of Medicine, Sofia University "St. Kliment Ohridski", 1407 Sofia, Bulgaria; dessislaval@yahoo.com

* Correspondence: bakalova.rumiana@qst.go.jp; Tel.: +81-80-81088136

check for

updates

Citation: Sumiyoshi, A.; Shibata, S.; Zhelev, Z.; Miller, T.; Lazarova, D.; Aoki, I.; Obata, T.; Higashi, T.; Bakalova, R. Targeting Glioblastoma via Selective Alteration of Mitochondrial Redox State. Cancers 2022, 14, 485. https://10.3390/ cancers 14030485

Academic Editor: Maxim V. Berezovski

Received: 6 December 2021 Accepted: 11 January 2022 Published: 19 January 2022

Publisher's Note: MDPI stays neutral with regard to jurisdictional claims in published maps and institutional affiliations.

Copyright: (c) 2022 by the authors. Licensee MDPI, Basel, Switzerland. This article is an open access article distributed under the terms and conditions of the Creative Commons Attribution (CC BY) license (https:// creativecommons.org/licenses/by/ $4.0 /)$.
Simple Summary: Glioblastoma is characterized by a pronounced redox imbalance due to elevated glycolytic and mitochondrial oxidative metabolism. New therapeutic strategies have been developed to modulate glioblastoma redox signaling to effectively suppress growth and prolong survival. However, drug selectivity and therapeutic relapse prove to be the major challenges. We describe a pharmacological strategy for the selective targeting and treatment of glioblastoma using the redox active combination drug menadione/ascorbate, which is characterized by tolerance to normal cells and tissues. Menadione/ascorbate treatment of glioblastoma mice suppressed tumor growth and significantly increased survival without adverse side effects. This is accompanied by increased oxidative stress, decreased reducing capacity and decreased cellular density in the tumor alone, as well as increased brain perfusion and decreased regulation of several oncoproteins and oncometabolites, which implies modulation of the immune response and reduced drug resistance. We believe that this therapeutic strategy is feasible and promising and deserves the attention of clinicians.

\begin{abstract}
Glioblastoma is one of the most aggressive brain tumors, characterized by a pronounced redox imbalance, expressed in a high oxidative capacity of cancer cells due to their elevated glycolytic and mitochondrial oxidative metabolism. The assessment and modulation of the redox state of glioblastoma are crucial factors that can provide highly specific targeting and treatment. Our study describes a pharmacological strategy for targeting glioblastoma using a redox-active combination drug. The experiments were conducted in vivo on glioblastoma mice (intracranial model) and in vitro on cell lines (cancer and normal) treated with the redox cycling pair menadione/ascorbate $(\mathrm{M} / \mathrm{A})$. The following parameters were analyzed in vivo using MRI or ex vivo on tissue and blood specimens: tumor growth, survival, cerebral perfusion, cellular density, tissue redox state, expression of tumor-associated NADH oxidase (tNOX) and transforming growth factor-beta 1 (TGF- $\beta 1$ ). Dosedependent effects of $\mathrm{M} / \mathrm{A}$ on cell viability, mitochondrial functionality, and redox homeostasis were evaluated in vitro. $\mathrm{M} / \mathrm{A}$ treatment suppressed tumor growth and significantly increased survival without adverse side effects. This was accompanied by increased oxidative stress, decreased reducing capacity, and decreased cellular density in the tumor only, as well as increased cerebral perfusion and down-regulation of tNOX and TGF- $\beta 1$. M/A induced selective cytotoxicity and overproduction of mitochondrial superoxide in isolated glioblastoma cells, but not in normal microglial cells. This was accompanied by a significant decrease in the over-reduced state of cancer cells and impairment of their "pro-oncogenic" functionality, assessed by dose-dependent decreases in: NADH, NAD", succinate, glutathione, cellular reducing capacity, mitochondrial potential, steady-state ATP, and tNOX expression. The safety of M/A on normal cells was compromised by treatment with cerivastatin, a non-specific prenyltransferase inhibitor. In conclusion, $\mathrm{M} / \mathrm{A}$ differentiates glioblastoma cells and tissues from normal cells and tissues by redox targeting, causing severe oxidative stress only in the
\end{abstract}


tumor. The mechanism is complex and most likely involves prenylation of menadione in normal cells, but not in cancer cells, modulation of the immune response, a decrease in drug resistance, and a potential role in sensitizing glioblastoma to conventional chemotherapy.

Keywords: glioblastoma; redox targeting; mitochondrial redox cycling; tumor-associated ENOX2; TGF- $\beta 1$; menadione; ascorbate

\section{Introduction}

Glioblastoma is one of the most aggressive brain tumors. The rate of occurrence is 5 per 100,000 individuals, leading to 225,000 deaths per year globally [1]. The median survival is approximately 5 months after diagnosis for untreated patients and very rarely exceeds 18-22 months after therapy [1-3]. Only 5\% of patients survive more than five years [4], and survival rates and mortality statistics for glioblastoma have remained unchanged for decades.

Surgical resection combined with radiotherapy and chemotherapy is the standard clinical protocol for this brain tumor, and temozolomide is still the "gold standard" for firstline chemotherapy of glioblastoma [5,6]. Temozolomide is a DNA-alkylating agent, which induces cell cycle arrest and apoptosis in cancer cells. It causes impressive suppression of tumor growth, but treatment with temozolomide is characterized by severe side effects $[7,8]$. In addition, DNA-alkylating anticancer drugs negatively affect all dividing normal cells in the organism such as immune, epithelial, and normal stem cells [9-11]. Some of these anticancer drugs also cause hemolysis [12]. This poses a risk of developing immune deficiency, anemia, and serious comorbidities because of chemotherapy.

Another major challenge in treating glioblastoma is how to avoid therapeutic relapse. Many advanced therapeutic strategies based on chemical or immunological mechanisms have been applied $[1,13,14]$, but the clinical effects are still modest in terms of median survival and recurrence. Enormous efforts and costs have been invested to discover new molecular targets for stopping the therapeutic resistance, as well as progression and invasion, of brain tumors [15]. However, currently available therapies have a palliative effect. The development and progression of glioblastoma, as well as its resistance to standard therapy, remain unclear.

Disruption of redox signaling and induction of redox imbalance in the cells and tissues, accompanied by moderate chronic oxidative stress, are decisive factors in triggering carcinogenesis, including in the brain [16-19]. Brain tissues are vulnerable to oxidative damage due to their high demand for oxygen and energy provided by high mitochondrial activity [20]. It is widely accepted that oxidative stress causes mitochondrial dysfunction and "vice versa", dysfunctional mitochondria are one of the main endogenous sources of oxidative stress in cancer because of incomplete coupling of electrons and $\mathrm{H}^{+}$with oxygen in the electron transport chain (ETC), contributing to further production of reactive oxygen species (ROS) [21,22]. Mitochondrial signaling directs various vital intracellular processes such as aerobic respiration, apoptosis, cell proliferation and survival, nucleic acid synthesis, and oxidative stress itself-all associated with cancer progression. The role of mitoepigenetic regulation in cancer cells and the potential employment of dysfunctional mitochondria as valuable anticancer targets were recently described by Chen et al. in their comprehensive review article [23]. In addition, tolerated oxidative stress in cancer is a consequence of increased basal metabolic activity and peroxisome activity, uncontrolled growth factors of cytokine signaling, oncogene activity, and enhanced activity of oxidase and oxygenase enzymes such as NADPH oxidase complex (NOX), cyclooxygenases, and lipoxygenases [24,25]. Cancer cells also express on their surface a unique tumor-associated hydroquinone (NADH) oxidase with protein disulfide-thiol exchange activity (tNOX/ENOX2), which contributes to the generation of ROS (mainly superoxide) 
and induction of oxidative stress [26,27]. This protein marker is a subject of interest in our study.

Glioblastoma is characterized by pronounced redox imbalance [28,29], expressed in the high oxidative capacity of cancer cells due to their elevated glycolytic and mitochondrial oxidative metabolism [30,31]. Glioblastoma cells rely on glycolysis as a source of energy but easily adapt to bioenergetic stress by activating and using their mitochondria and oxidative phosphorylation (OXPHOS) to survive and grow [32]. Thus, these cells break out of metabolic restrictions and adapt to their microenvironment. Recently, it was reported that mitochondrial fatty acid oxidation $(\mathrm{mFAO})$ is overexpressed in these cells $[33,34]$. They use fatty acids as a fuel for energy production and perhaps for other reasons, especially when glucose is not sufficient. Abnormal mitochondrial functionality has been linked to the development of glioblastoma [32-34]. These findings imply that the assessment and modulation of the redox state and function of cancerous mitochondria are key factors that may provide highly specific targeting and treatment of this brain cancer.

ROS/RNS (superoxide, hydrogen peroxide, other hydroperoxides, nitric oxide, etc.) and reducing equivalents (NADH, NADPH, antioxidants, etc.) are often described as "redoxactive compounds", and the balance between them as the "redox status", "redox state", or "bioreduction capacity" of cells, tissues, and body fluids [35]. Changes in their spatial and temporal distribution play a central role in carcinogenesis [36]. Currently, the redox state is considered an important diagnostic marker and a therapeutic target for all pathologies associated with a disturbance in cellular redox signaling. The tissue redox state is analyzed by using exogenous redox-sensitive molecular probes and imaging techniques. This methodological approach shows that early-stage glioblastoma in animals is characterized by a high reducing capacity, and the same is true for the tissues of healthy individuals $[29,37]$. In contrast, the microenvironment of moderate- and advanced-stage glioblastoma is characterized by decreased reducing capacity and increased oxidative activity compared to healthy tissues [29,37], which contributes to genomic instability [24,38].

It has also been shown that cancer progression affects the redox state of healthy tissues distant from the primary tumor locus $[29,37]$. The oxidative capacity of these tissues increases, and they become vulnerable to oxidative stress and damage [29]. This could be crucial to inducing side effects, tumor invasion, and resistance to therapy $[29,37]$.

The oxidative activity of cancer cells and tissues is due to abnormal ROS/RNS levels and not necessarily associated with high oxygen tension. On the contrary, hypoxia is a hallmark of solid tumors such as glioblastoma. Hypoxic signaling pathways have important implications for the adaptation of cancer cells to oxidative stress, the induction of uncontrolled proliferation, and immortalization. The correlation between oxidative stress, hypoxia, and resistance of glioblastoma tumors to radiotherapy is sufficiently described in Torrisi et al. [39].

It has also been shown that cancer progression affects the redox state of healthy tissues distant from the primary tumor locus $[29,37]$. The oxidative capacity of these tissues increases, and they become vulnerable to oxidative stress and damage [29]. This could be crucial to inducing side effects, tumor invasion, and resistance to therapy $[29,37]$.

It is well known that redox imbalance and oxidative stress contribute to inflammation $[21,24,25]$. Some of the most frequently discussed endogenous substances, responsible for the spread of inflammation away from the primary tumor and affecting the redox homeostasis of healthy tissues, are proinflammatory cytokines produced by tumor-associated macrophages and fibroblasts [40,41]. Our study considers the role of transforming growth factor beta complex 1 (TGF- $\beta 1$ ) in glioblastoma, as a prominent proinflammatory cytokine known to contribute to the spread of inflammation, fibrosis, and metastasis [42].

Many studies now clearly demonstrate that the redox environment plays an important role in the initiation, progression, and regression of glioblastoma, and new targeted redox therapies should be the focus of scientists, pharmacists, and clinicians. In the last decade, new therapeutic strategies have been designed to modulate redox signaling in this brain tumor, to improve immune recognition and immune response, and to potentiate the effect of 
standard therapy [28,43-45]. Most of the redox-active compounds found to be cytotoxic to glioblastoma cells are characterized by overproduction of ROS, including overproduction of mitochondrial ROS, a decrease in mitochondrial potential, and/or depletion of glutathione (Table S1, see the Supporting Materials). However, most of them have not been studied for selectivity towards glioblastoma cells only, and off-target effects limit their prospects.

In this article, we describe highly selective targeting and treatment of glioblastoma in vitro and in vivo, using the redox-active combination drug menadione/ascorbate (M/A, $1 / 100 \mathrm{~mol} / \mathrm{mol}$ ratio). It has been empirically established that at a ratio of $1 / 100(\mathrm{~mol} / \mathrm{mol})$, this combination exhibits the strongest synergistic cytotoxicity towards cancer cells compared to other ratios such as $1 / 10$ and $1 / 50$. This effect is thought to be due to the redox cycling between the two molecules in the cells and the extracellular environment, which requires an excess of ascorbate and leads to the overproduction of ROS (Figure S1, see the Supporting Materials). The mechanism and the combination index are described in many articles summarized recently in [46]. M/A has attracted the attention of researchers due to the synergistic anticancer effect of the two molecules, as well as its ability to kill cancer cells without affecting the viability of normal cells [46]. Importantly, the strong synergistic antiproliferative and cytotoxic effect on cancer cells is inherent for the combination of ascorbate and menadione (pro-vitamin K3), but not for the combination of ascorbate and vitamin $\mathrm{K} 1$ or $\mathrm{K} 2$ [46]. This suggests that the prenylation of menadione and its conversion into vitamin $\mathrm{K} 1$ or $\mathrm{K} 2$ will decrease its anticancer activity in combination with ascorbate. In this context, inhibitors of prenyltransferase and the mevalonate pathway should potentiate the effect of M/A. However, it is not known how this triple combination will affect the homeostasis of normal cells and tissues, and whether this mechanism underlies the selective cytotoxicity of M/A against cancer cells only.

Menadione and ascorbate are known to interfere with the mitochondrial ETC. Studies have demonstrated that menadione and other quinones affect mitochondrial respiration directly and even provide explanations for the molecular mechanisms of this mitochondrial interference [47-49]. For example, it has been demonstrated that pharmacological ascorbate and menadione are beneficial in the treatment of mitochondrial diseases, bypassing Complex I and Complex III deficiency $[47,49,50]$. The combination of ascorbate and menadione has been included in the "List of Dietary Supplements for Primary Mitochondrial Disorders" by the U.S. Department of Health and Human Services, National Institute of Health (NIH). Menadione and ascorbate have been applied as a dietary supplement in combination with coenzyme Q10, niacin, riboflavin, and thiamin to bypass Complex I and Complex III of the mitochondria [51].

Experiments on animal models demonstrated that the anticancer effect of $M / A$ is apparent at low, pharmacologically achievable doses. This differs significantly from the vitamin activity of the two molecules. Studies also suggest that ascorbate should not be considered simply as a pro-oxidant or antioxidant [52,53]. Ascorbate is one of the most abundant cytosolic redox-active compounds and could serve as a "buffer" of excessreducing equivalents in the intracellular aqueous phase of cancer cells due to their oxidative environment. Steady-state levels of ascorbate are maintained by the NADH-dependent cytochrome b5 reductase 3 (Cyb5R3) [54,55], and they are significantly higher in cancer cells compared to normal cells due to overexpression of vitamin C transporters (glucose transporter 1 (GLUT1) and sodium-dependent vitamin C transporters 1 and 2 (SVCT1, SVCT2)) [56].

Menadione is known to cross the blood-brain barrier (BBB) [57]. Ascorbate has been shown to cross the BBB via GLUT1 in its oxidized form and via SVCT1 and SVCT2 in its oxidized and reduced forms [57-59]. Brain tissues contain some of the highest ascorbic acid concentrations among mammalian tissues. Intracellular ascorbate is involved in the physiology of the nervous system, including the processes of differentiation, maturation, and neuronal survival, modulation of neurotransmission, myeline formation, protection against glutamate toxicity, and others $[58,59]$. 
The aim of the present study was to elucidate the possibility of targeting and treating glioblastoma with the redox-active combination drug menadione/ascorbate by selectively altering the redox state of cancerous (dysfunctional) mitochondria. The experiments were conducted in vitro on human glioblastoma cells (U87MG) and normal microglial cells, as well as in vivo on glioblastoma-bearing mice (U87MG intracranial model). Our efforts were directed to clarifying: (i) the molecular mechanism(s) for recognizing dysfunctional mitochondria by $\mathrm{M} / \mathrm{A}$ and altering their redox state in glioblastoma cells and tissues, without significantly affecting the homeostasis of healthy cells and tissues; (ii) the role of two key proteins, $\mathrm{tNOX}$ and TGF- $\beta 1$, for the induction of oxidative stress in the tumor, as well as for changing the redox state of healthy tissues and their vulnerability to oxidative damage. Up-regulation of $\mathrm{tNOX}$ and/or TGF- $\beta 1$ has been found to correlate with a poor prognosis and low survival in patients with glioblastoma $[26,27,42,60]$. The effect of M/A treatment on cerebral blood flow (CBF) and the apparent diffusion coefficient (ADC) was also analyzed by using MRI in vivo. In recent years, these parameters have been accepted as potential non-invasive biomarkers for monitoring and predicting the response of brain tumors to anticancer therapy and their malignancy by using multiparametric MRI [61,62].

\section{Materials and Methods}

\subsection{Chemicals}

L-Ascorbic acid and menadione were purchased from Sigma-Aldrich (Weinheim, Germany).

All reagents used in the experiments were "analytical grade" or "HPLC grade".

\subsection{Cells and Treatment Protocol}

The experiments were performed on normal and cancer cell lines, purchased from ATCC ${ }^{\circledR}$, Washington, DC, USA (U87MG, EOC2).

U87MG cells were cultured in DMEM (Sigma-Aldrich, Weinheim, Germany), supplemented with $10 \%$ FBS and antibiotics $(100 \mathrm{U} / \mathrm{mL}$ penicillin and $100 \mu \mathrm{g} / \mathrm{mL}$ streptomycin). EOC2 cells were cultured in DMEM, supplemented with $10 \%$ FBS. Cells were cultured in a humidified atmosphere at $37^{\circ} \mathrm{C}$, saturated with $5 \% \mathrm{CO}_{2}$.

To remove the adhesive cells from the plates, we used a trypsin/EDTA solution $(0.05 \%$ of trypsin/EDTA; Sigma-Aldrich, Weinheim, Germany) for U87MG, and a cell scraper for EOC2.

The cells were collected by centrifugation $(125 \times \mathrm{g}$ for $10 \mathrm{~min})$ and placed in a fresh medium without antibiotics prior to treatment with the respective substance. The cells $\left(3 \times 10^{5}\right.$ cells $\left./ \mathrm{mL}\right)$ were incubated with the drug for different time intervals in a cell incubator. At each time interval, aliquots were used for analyses.

Ascorbate was dissolved in PBS (10 mM, pH 7.4). Menadione was dissolved in dimethyl sulfoxide (DMSO; Sigma-Aldrich, Weinheim, Germany) to $10 \mathrm{mM}$ stock solutions, and then several working solutions in PBS were prepared. The final concentration of DMSO in the cell suspension was below 1\%. At this concentration, DMSO did not affect cell viability.

\subsection{Cell Proliferation and Viability Assays}

Cell proliferation and viability were analyzed using CellTiter-Glo ${ }^{\mathrm{TM}}$ Luminescent Cell Viability Assay (Promega, Madison, WI, USA).

Briefly, $100 \mu \mathrm{L}$ aliquots of cell suspensions were placed in 96-well plates and incubated with $\mathrm{M} / \mathrm{A}$ for 24 and $48 \mathrm{~h}$, in a humidified atmosphere (at $37^{\circ} \mathrm{C}, 5 \% \mathrm{CO}_{2}$ ). An amount of $100 \mu \mathrm{L}$ of CellTiter-Glo reagent (containing luciferin and luciferase) was added to each well, followed by incubation using the protocol recommended by the manufacturer. The luminescence, produced by the luciferase-catalyzed conversion of luciferin into oxyluciferin by living cells, was detected using a microplate reader (TECAN Infinite ${ }^{\circledR}$ M1000, Vienna, Austria), working in a chemiluminescent mode.

The linear range for this assay was up to $5 \times 10^{5}$ cells per well. 


\subsection{Apoptosis Assay}

The induction of apoptosis was analyzed by the expression of phosphatidylserine (PSer) on the cell surface, using FITC-Annexin V Apoptosis Detection Kit (BioVision, Milpitas, CA, USA). Briefly, the cells $\left(5 \times 10^{5}\right.$ cells $\left./ \mathrm{mL}\right)$ were incubated with $\mathrm{M} / \mathrm{A}$ for $48 \mathrm{~h}$ in a humidified atmosphere. The cell medium was removed, and $100 \mu \mathrm{L}$ of PBS containing $2.5 \mathrm{mM}$ of $\mathrm{CaCl}_{2}$ (annexin V-binding buffer) and $5 \mu \mathrm{L}$ of fluorescein isothiocyanate (FITC)annexin $\mathrm{V}$ were added to each well and incubated for $10 \mathrm{~min}$ at room temperature in the dark. The cells were washed three times with annexin V-binding buffer and resuspended in the same buffer. FITC-annexin V bound to PSer exposed on the cell surface was detected spectrofluorimetrically at $\lambda_{\mathrm{ex}}=488 \mathrm{~nm}$ and $\lambda_{\mathrm{em}}=535 \mathrm{~nm}$, using a microplate reader (TECAN Infinite ${ }^{\circledR}$ M1000, Vienna, Austria).

\subsection{Mitochondrial Superoxide Assay}

MitoSOX ${ }^{\mathrm{TM}}$ Red Mitochondrial Superoxide Indicator (Molecular Probes, Invitrogen, Oregon, OR, USA) is a fluorogenic probe for highly selective detection of superoxide in the mitochondria of live cells. The probe is a dihydroethidium derivate, containing a triphenylphosphonium group. Once in the mitochondria, MitoSOX ${ }^{\mathrm{TM}}$ Red reagent is oxidized by superoxide and exhibits red fluorescence. The probe is not oxidized by other ROS/RNS, and its oxidation is prevented by superoxide dismutase [63].

Briefly, MitoSOX ${ }^{\mathrm{TM}}$ Red was dissolved in DMSO to a $5 \mathrm{mM}$ stock solution, which was diluted with Hank's Balanced Salt Solution (HBSS, containing $\mathrm{Ca}^{2+}$ and $\mathrm{Mg}^{2+}$ ) to prepare $3 \mu \mathrm{M}$ MitoSOX ${ }^{\mathrm{TM}}$ Red working solution on the day of the experiment. One milliliter of cells $\left(5 \times 10^{5}\right.$ cells $\left./ \mathrm{mL}\right)$ was collected by centrifugation, and the pellet was resuspended in $1 \mathrm{~mL}$ of $3 \mu \mathrm{M}$ MitoSOX ${ }^{\mathrm{TM}}$ Red. The samples were incubated for $30 \mathrm{~min}$ at room temperature, protected from light, washed three times with PBS using centrifugation, and finally resuspended in $1 \mathrm{~mL}$ of PBS. The fluorescence intensity was detected immediately at $\lambda_{\mathrm{ex}}=510 \mathrm{~nm}$ and $\lambda_{\mathrm{em}}=580 \mathrm{~nm}$, using a microplate reader (TECAN Infinite ${ }^{\circledR}$ M1000, Vienna, Austria).

\subsection{Mitochondrial Membrane Potential}

The mitochondrial membrane potential was analyzed using tetramethylrhodamine methyl ester (TMRE; Sigma-Aldrich, Weinheim, Germany) as described in Levraut et al. [64], with slight modifications. TMRE is a cell-penetrating, cationic fluorophore, which accumulates in the mitochondrial matrix based on the mitochondrial membrane potential. The fluorescence intensity is proportional to the mitochondrial potential and decreases upon depolarization of the mitochondrial membrane.

Briefly, $1 \mathrm{~mL}$ of cells $\left(5 \times 10^{5}\right.$ cells $\left./ \mathrm{mL}\right)$ were placed in 12 -well plates. An amount of $5 \mu \mathrm{L}$ of TMRE (from a $40 \mu \mathrm{M}$ stock solution in DMSO) was added to each well. The samples were incubated at $37^{\circ} \mathrm{C}$ for $30 \mathrm{~min}$, washed twice with PBS using centrifugation, and finally resuspended in $1 \mathrm{~mL}$ of PBS. The fluorescence intensity was detected immediately at $\lambda_{\mathrm{ex}}=550 \mathrm{~nm}$ and $\lambda_{\mathrm{em}}=575 \mathrm{~nm}$, using a microplate reader (TECAN Infinite ${ }^{\circledR} \mathrm{M} 1000$, Vienna, Austria).

\subsection{Succinate Assay}

The succinate level was analyzed using Succinate Assay Kit (Colorimetric) (Abcam, Tokyo, Japan). The analysis is based on a coupled enzyme reaction, which results in a colored product with absorbance reaching a maximum at $450 \mathrm{~nm}$, which is proportional to the succinate concentration in the sample. Succinate was used as a standard.

Briefly, cells $\left(1 \times 10^{6}\right.$ cells per sample) were lysed in $100 \mu \mathrm{L}$ of succinate assay buffer as described in the manufacturer's instructions. An amount of $50 \mu \mathrm{L}$ (in duplicates) of each cell lysate was placed in a 96-well plate and incubated with $50 \mu \mathrm{L}$ of reaction mix-1 or $50 \mu \mathrm{L}$ of reaction mix-2 (without succinate converter; blank sample) for $20 \mathrm{~min}$ at $37^{\circ} \mathrm{C}$, in the dark. Absorbance at $450 \mathrm{~nm}$ was recorded, using a microplate reader (TECAN Infinite ${ }^{\circledR}$ 
M1000, Vienna, Austria). A blank sample was included to correct the NADH-dependent background absorbance.

\section{8. $\mathrm{NAD}^{+} / \mathrm{NADH}$ Quantification Assay}

The $\mathrm{NAD}^{+} / \mathrm{NADH}$ level was analyzed using NAD ${ }^{+} / \mathrm{NADH}$ Quantification kit (SigmaAldrich, St. Louis, MO, USA). This assay is specific for $\mathrm{NAD}^{+}$and $\mathrm{NADH}$ and does not detect $\mathrm{NADP}^{+}$and NADPH. NAD total and NADH are quantified spectrophotometrically at $450 \mathrm{~nm}$.

Briefly, cells $\left(2 \times 10^{5}\right.$ cells per sample) were placed in $100 \mu \mathrm{L} \mathrm{NAD}^{+} / \mathrm{NADH}$ extraction buffer and homogenized as described in the manufacturer's instructions. Cell lysates were purified on a $10 \mathrm{kDa}$ cut-off spin filter. An amount of $50 \mu \mathrm{L}$ (in duplicates) of each sample was placed in a 96-well plate and incubated with $100 \mu \mathrm{L}$ of master reaction mix for $5 \mathrm{~min}$ at room temperature to convert $\mathrm{NAD}^{+}$to $\mathrm{NADH}$ (for $\mathrm{NAD}_{\text {total }}$ determination). An amount of $10 \mu \mathrm{L}$ of NADH developer was added to each sample and incubated for $1 \mathrm{~h}$ at room temperature. Absorbance at $450 \mathrm{~nm}$ was recorded, using a microplate reader (TECAN Infinite ${ }^{\circledR}$ M1000, Vienna, Austria). For detection of NADH only, aliquots of cell lysates were placed in a heating block for $30 \mathrm{~min}$ at $60^{\circ} \mathrm{C}$, to decompose $\mathrm{NAD}^{+}$, before proceeding to analysis.

\subsection{Total Glutathione Assay}

The total glutathione (GSH/GSSG) in cell suspensions $\left(5 \times 10^{6}\right.$ cells $\left./ \mathrm{mL}\right)$ was analyzed by OxiSelect ${ }^{\mathrm{TM}}$ Total Glutathione (GSSG/GSH) Assay kit (Cell Biolabs, Inc., San Diego, CA, USA) as described in the manufacturer's instructions. The method is based on the reduction of GSSG to GSH by glutathione reductase in the presence of NADPH and the subsequent addition of chromogen. Chromogen reacts with the thiol group of GSH, with the production of a spectrophotometrically detectable compound at $405 \mathrm{~nm}$, using a microplate reader (TECAN Infinite ${ }^{\circledR}$ M1000, Vienna, Austria). The total glutathione content in the cell suspension was determined by a calibration curve using a glutathione standard.

\subsection{Total Antioxidant Capacity (TAC) Assay}

The TAC assay was performed on cell and tissue lysates using OxiSelect ${ }^{\mathrm{TM}}$ Total Antioxidant Capacity (TAC) Assay kit (Cell Biolabs, Inc., San Diego, CA, USA). The method is based on the reduction of $\mathrm{Cu}^{2+}$ to $\mathrm{Cu}^{+}$by antioxidants and other reducing equivalents in the biological sample. $\mathrm{Cu}^{+}$interacts with a chromophore to obtain a color product with an absorption maximum at $490 \mathrm{~nm}$. The value of absorption is proportional to the total antioxidant and reducing capacity of the biological object.

Briefly, cell and tissue lysates were prepared as described in the manufacturer's instructions. All lysates were adjusted to the same protein concentration, and $20 \mu \mathrm{L}$ of aliquots was placed in a 96-well plate. Each sample was incubated with a copper ion reagent and chromophore as described in the instruction. The absorption of the product at $490 \mathrm{~nm}$ was detected by a microplate reader (TECAN Infinite ${ }^{\circledR}$ M1000, Vienna, Austria). Three independent experiments were performed for each lysate, with two parallel sample measurements for each experiment.

The total antioxidant capacity of the samples was determined by a calibration curve using uric acid as a standard. The results are presented as "Total Antioxidant Capacity (TAC)", which is equivalent to "Total Reducing Capacity" in "mM Uric Acid Equivalents". An amount of $1 \mathrm{mM}$ of uric acid corresponds to $2189 \mu \mathrm{M}$ of $\mathrm{Cu}^{2+}$-reducing equivalents.

\subsection{1. tNOX (ENOX2) Assay}

Ecto-NOX disulfide-thiol exchanger 2 (ENOX2, tNOX) expression was detected in cell and tissue lysates using Human ENOX2 ELISA kit (Cusabio, Huston, TX, USA) and Mouse ENOX2 ELISA kit (LifeSpan BioScience, Seattle, WA, USA), respectively. Cell and tissue lysates were prepared and analyzed as described in the manufacturer's instructions. The protein concentration in the lysates was determined by Bradford analysis. Both assays 
are based on the quantitative sandwich enzyme immunoassay technique. The antigenantibody complex was detected spectrophotometrically at $450 \mathrm{~nm}$, based on the oxidation of 3,3'5,5'-tetramethylbenzidine (TMB) by horseradish peroxidase conjugated to avidin, which interacts with the biotinylated secondary antibody in the sandwich. Lyophilized tNOX (ENOX2) protein was used as a standard. All samples were run in triplicate.

\subsection{TGF- $\beta 1$ Assay}

Transforming growth factor-beta 1 (TGF- $\beta 1$ ) expression was detected in plasma using Human TGF- $\beta 1$ ELISA kit (Funakoshi, Tokyo, Japan) and Mouse TGF- $\beta 1$ ELISA kit (Abcam, Tokyo, Japan). Samples were collected and stored at $-80^{\circ} \mathrm{C}$ for approximately one month before the analysis of TGF- $\beta 1$ and then analyzed, as described in the manufacturer's instructions.

The assay is based on the quantitative sandwich enzyme immunoassay technique. The antigen-antibody complex was detected spectrophotometrically at $450 \mathrm{~nm}$ (and $570 \mathrm{~nm}$ as a reference wavelength), based on the oxidation of $3,3^{\prime} 5,5^{\prime}$-tetramethylbenzidine (TMB) by horseradish peroxidase conjugated to streptavidin, which interacts with the biotinylated secondary antibody in the sandwich. Lyophilized TGF- $\beta 1$ protein was used as a standard. All samples were run in triplicate.

\subsection{Animals and Treatment Protocol}

The animal experiments in this study were approved by the National Institutes for Quantum Science and Technology (QST) Institutional Animal Care and Use Committee, Chiba, Japan, and all experiments were performed in accordance with relevant guidelines and regulations.

BALB/c nude mice were obtained from Charles River Labs (Tokyo, Japan). All mice were male, used at 6-8 weeks of age, and maintained in specific pathogen-free conditions.

U87MG glioblastoma model: The experimental design is shown in Figure S2 (in the Supporting Materials). Human glioblastoma U87MG cells $\left(1 \times 10^{5}\right.$ in $2 \mu \mathrm{L}$ per mouse) were inoculated into the brain of anesthetized mice using a stereotaxic device (SR-6M, Narishige, Tokyo Japan). The cell suspension was injected $2 \mathrm{~mm}$ to the right of and $1 \mathrm{~mm}$ anterior from the bregma, at a depth of $3 \mathrm{~mm}$ within $2 \mathrm{~min}$. The glioma-bearing mice were assigned to the following two groups: (i) control group-single intracranial injection of saline solution; (ii) M/A-treated group_single intracranial injection of $70 \mu \mathrm{g} / 7 \mathrm{mg}$ of $\mathrm{M} / \mathrm{A}$ per $\mathrm{kg}$ body weight. The volume of all intracranial injections of $\mathrm{M} / \mathrm{A}$ was $5 \mu \mathrm{L}$. The mice in the $\mathrm{M} / \mathrm{A}$-treated group were also subjected to oral administration of $\mathrm{M} / \mathrm{A}$ in the drinking water $(150 \mathrm{mg} / 15 \mathrm{~g}$ of M/A per $1 \mathrm{~L}$; freshly prepared every day except on weekends). The mice in the control group received $\mathrm{M} / \mathrm{A}$-free water. One day before cell transplantation, the mice were placed on a vitamin C- and menadione-deficient diet (CLEA, Tokyo, Japan).

Before injection of the drug, the tumor was visualized in the brain of each mouse using $\mathrm{T}_{2}$-weighted $\left(\mathrm{T}_{2} \mathrm{~W}\right) \mathrm{MRI}$, and the initial tumor size was calculated. Body weight was measured once or twice per week. MRI measurements were also performed once or twice per week depending on parameters analyzed. The approved humane endpoint was two months after cell transplantation. However, the mice were sacrificed at the following conditions: when the tumor size exceeded $100 \mathrm{~mm}^{3}$, or at rapid weight loss of $25 \%$, headedness, and/or tetraplegia.

\subsection{Measurement of Hemoglobin, Hematocrit, and Thrombosis}

$\mathrm{Hb}$ and Hct were measured by a Start Strip Xpress2 device (Nova Biomedical, Waltham, MA, USA), and prothrombin time was measured by test trips for the CoaguChek ${ }^{\circledR}$ XS system (Roche Diagnostics K.K., Tokyo, Japan) using peripheral blood taken from the tail (after disinfection) of mice anesthetized with isoflurane. The presence of thrombosis was assessed by light microscopy. 


\subsection{In Vivo MRI Measurements}

Each mouse was anesthetized with isoflurane (3\% for initial induction and 1-2\% during MRI scanning) and was placed in the prone position on a custom-built MRI stage with a bite bar and a facemask. The respiration rate was monitored using a respiration sensor (SA Instruments, Inc., New York, NY, USA) and was regulated at 80-120 breaths per minute. The core body temperature was monitored with a rectal probe (FOT-M and FTI-10, FISO Technologies Inc., Quebec, Canada) and was regulated at $37.0 \pm 1.0^{\circ} \mathrm{C}$ using a water-circulating pad and a warm circulation air system. MRI data were acquired using a horizontal 7.0 T Bruker BioSpec 70/40 MRI system with an $86 \mathrm{~mm}$ volume transmit and a 4-channel phased array receive-only cryoprobe (Bruker Biospin, Ettlingen, Germany). The software and console of the MRI scanner were ParaVision 360 and AVANCE NEO, respectively. Following the standard adjustment routines, pilot scans (Tripilot sequence) were used for accurate positioning of the animal head inside the magnet.

The $\mathrm{T}_{2} \mathrm{~W}$ images were obtained using a spin echo 2D-RARE (rapid acquisition with relaxation enhancement) pulse sequence with the following parameters: repetition time $=$ $3000 \mathrm{~ms}$, effective echo time $=60 \mathrm{~ms}$, $R A R E$ factor $=8$, field of view $=16 \times 16 \mathrm{~mm}^{2}$, matrix size $=160 \times 160$, in-plane resolution $=0.1 \times 0.1 \mathrm{~mm}^{2}$, number of slices $=13$, slice thickness $=0.3 \mathrm{~mm}$, slice gap $=0 \mathrm{~mm}$, fat suppression $=$ on, and number of averages $=8$.

CBF images were obtained using a 2D-FAIR (flow-sensitive alternating inversion recovery) RARE pulse sequence with the following parameters: inversion recovery time $=100,300,500,700,900,1100,1300,1500,1700$, and $1900 \mathrm{~ms}$, repetition time =12,000 ms, effective echo time $=4.54 \mathrm{~ms}$, RARE factor $=20$, field of view $=16 \times 16 \mathrm{~mm}^{2}$, matrix size $=80 \times 80$, in-plane resolution $=0.2 \times 0.2 \mathrm{~mm}^{2}$, number of slices $=1$, slice thickness $=$ $0.75 \mathrm{~mm}$, and number of averages $=1$.

ADC images were obtained using a diffusion (2D-DtiStandard Diffusion Tensor Imaging Standard) pulse sequence with the following parameters: diffusion gradient duration = $2.5 \mathrm{~ms}$, diffusion gradient separation $=8.4 \mathrm{~ms}$, diffusion $\mathrm{b}$-value $=800 \mathrm{~s} / \mathrm{mm}^{2}$, repetition time $=2500 \mathrm{~ms}$, echo time $=17.5 \mathrm{~ms}$, field of view $=16 \times 16 \mathrm{~mm}^{2}$, matrix size $=160 \times 160$, in-plane resolution $=0.1 \times 0.1 \mathrm{~mm}^{2}$, number of slices $=1$, slice thickness $=0.75 \mathrm{~mm}$, and number of averages $=1$.

MRI data analysis was performed using custom-written software in MATLAB (MathWorks, Natick, MA, USA). CBF image analysis consists of calculations of the selective $\mathrm{T}_{1}$ map $\left(\mathrm{T} 1_{\text {sel }}\right)$, calculation of the global $\mathrm{T}_{1}$ map $\left(\mathrm{T} 1_{\text {nonsel }}\right)$, and calculation of the perfusion map $(\mathrm{CBF})$. The calculations of $\mathrm{T} 1_{\text {sel }}$ and $\mathrm{T} 1_{\text {nonsel }}$ were performed using a nonlinear least square fit to the data for each voxel in the images with different inversion recovery times (10 images in each). CBF was calculated from the measurements of $\mathrm{T} 1_{\text {sel }}$ and $\mathrm{T} 1_{\text {nonsel }}$, which were obtained using the equation: $\mathrm{CBF}(\mathrm{mL} / 100 \mathrm{~g} / \mathrm{min})=\lambda * \mathrm{~T} 1_{\text {nonsel }} / \mathrm{T} 1_{\text {blood }} *\left(1000 / \mathrm{T} 1_{\text {sel }}\right.$ $\left.-1000 / \mathrm{T} 1_{\text {nonsel }}\right)$, where $\lambda$ is the blood-brain partition coefficient, i.e., the ratio between the water concentration per gram of brain tissue and per milliliter of blood. $\lambda$ was set to 4980. $\mathrm{T}_{\text {blood }}$ was set to 2.3 , which was derived from the measurements of rat blood at $7.0 \mathrm{~T}$. ADC images were obtained using the equation: $\operatorname{ADC}\left(\mathrm{mm}^{2} / \mathrm{s}\right)=1 / \mathrm{b}_{1} * \ln \left[\mathrm{SI}\left(\mathrm{b}_{0}\right) / \mathrm{SI}\left(\mathrm{b}_{1}\right)\right]$, where $S I\left(b_{0}\right)$ and $S I\left(b_{1}\right)$ are the image intensities obtained by two gradient $b$-values, $b_{0}=0$ and $b_{1}=800 \mathrm{~s} / \mathrm{mm}^{2}$. For the region-of-interest (ROI) analysis, the image segmentation was performed with ITK-SNAP software and custom-written software in MATLAB.

For redox imaging, five control images of the mouse brain were taken before injection with the following parameters: $T_{1}$-weighted $\left(T_{1} W\right)$ incoherent gradient echo sequence $($ FLASH $)$, repetition time $=75 \mathrm{~ms}$; echo time $=3.5 \mathrm{~ms}$; flip angle $=45$ degrees; field of view $=3.2 \times 3.2 \mathrm{~cm}$; number of averages $=4$; scan time $=19.6 \mathrm{~s}$; matrix $=64 \times 64$; slice thickness $=1.0 \mathrm{~mm}$; and number of slices $=4$. A solution of a nitroxide derivative (multi-spin mitoTEMPO dissolved in PBS, $\mathrm{pH} 7.4)$ was injected via the tail vein (100 $\mu \mathrm{L}$ per $25 \mathrm{~g}$ mouse; $0.4 \mu \mathrm{mol} / \mathrm{g}$ b.w.) $100 \mathrm{sec}$ after beginning the scan. $\mathrm{T}_{1} \mathrm{~W}$ images were acquired continuously within approximately $14 \mathrm{~min}$, using the parameters described above. The final dose of nitroxide was much lower than the $\mathrm{LD}_{50}$ value calculated for i.v. administration in nude mice. The averaged value of the first five control sequences (recorded before injection of 
nitroxide) was calculated, and each sequence of the kinetic measurement was normalized to this averaged value.

\subsection{Statistical Analysis}

All results are expressed as the mean \pm standard deviation (SD). The normality of the distribution for all parameters of each experimental group in vivo was initially confirmed by using the Kolmogorov-Smirnov test. The most extreme differences for all experimental groups were below the critical D-values. Based on the normality of the distribution in all groups, the comparisons between them were performed using Student's $t$-test for multiple comparisons. Two-tailed $p$-values of less than 0.05 were considered statistically significant.

\section{Results}

\subsection{Effect of $M / A$ on Tumor Growth and Survival of Glioblastoma-Bearing Mice}

The mice were inoculated with U87MG cells, and after 7 days, tumors were visualized in the animals, using MRI. The initial tumor size was approximately $15-20 \mathrm{~mm}^{3}$. The mice were divided into two groups: $\mathrm{M}$ /A-treated group-single intracranial injection of $\mathrm{M} / \mathrm{A}$ plus daily oral administration of $\mathrm{M} / \mathrm{A}$ in the drinking water; control group-single intracranial injection of saline solution.

The tumor size was measured each week after cell transplantation (Figure 1A). In the M/A-treated group, tumor growth was significantly slower compared to the control group (Figure 1A,B). In the control group, there was a 2-fold increase in the tumor size for a week ( $p<0.001$; Figure $1 C$ ), while single intracranial injection of $\mathrm{M} / \mathrm{A}$ stopped tumor growth for a week (Figure 1D). M/A-treated mice had longer survival than the control mice (Figure 1E). Median survival was $39.3 \pm 4.3$ days for the $\mathrm{M} / \mathrm{A}$-treated group versus $25.9 \pm 5.4$ days for the control group $(p<0.01$; Figure $1 F)$. The body weight in both experimental groups was relatively stable (Figure 1G). M/A-treated mice lost weight after 34 days of cell transplantation.

Single intracranial injection and oral administration of M/A in glioblastoma-bearing mice did not affect the levels of hemoglobin $(\mathrm{Hb})$ and hematocrit $(\mathrm{Hct})($ Figure $1 \mathrm{H})$. Hemolysis and erythropenia were not detected even after single intravenous injection of M/A (in doses up to $140 \mu \mathrm{g} / 14 \mathrm{mg}$ per $\mathrm{kg}$ body weight) in mice, which exceeds twice the intracranial dose used in our study. Intravenous injection of $\mathrm{M} / \mathrm{A}$ at the same dose did not affect the prothrombin time (Figure $1 \mathrm{H}$ ) and did not lead to thrombosis (Figure S3 in the Supporting Materials). All hematological parameters were within the respective reference values before and after M/A treatment. This is direct evidence that menadione does not act as a coagulant when used in combination with ascorbate in doses with a pronounced anticancer effect. M/A at concentrations up to $20 / 2000 \mu \mathrm{M} / \mu \mathrm{M}$, exceeding those that can be achieved pharmacologically, did not affect the viability of normal human lymphocytes and normal human epithelial cells, which was analyzed in vitro in our previous study $[46,65]$.

\subsection{Effect of $M / A$ on Brain Perfusion and Cell Density of Glioblastoma-Bearing Mice}

Using multiparametric MRI analysis, we assessed the effects of M/A on CBF and ADC, characterizing the homeostasis of the brain tumors and their potential susceptibility to therapy. Two regions of interest (ROIs) were defined in the brain for this analysis: (i) tumor area; (ii) contralateral hemisphere (Figure 1I). The values of CBF and ADC in both ROIs of the untreated (control) and $\mathrm{M} / \mathrm{A}$-treated glioblastoma mice are shown in Figure 1J,K. A significant increase in CBF values was observed in both ROIs of the M/Atreated group compared to the untreated group ( $\sim 3$ times in the tumor area and $\sim 50 \%$ in the contralateral hemisphere) (Figure $1 \mathrm{~K}$ ). M/A treatment increased the values of ADC in the tumor area $(\sim 15 \%, p<0.01)$, but not in the contralateral hemisphere, compared to the untreated glioblastoma mice (Figure 1I). 
A

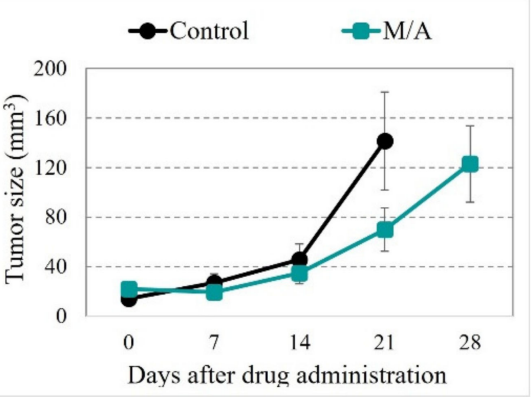

B M/A versus Control 3-weeks after injection

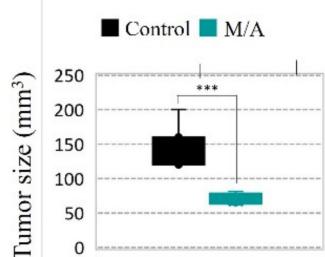

C

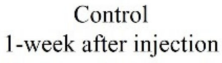

$\mathrm{D}$ 1-week after injection

Before After 1-w

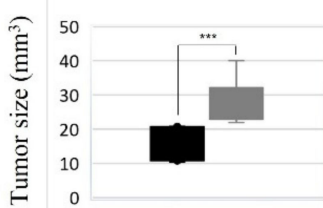

E

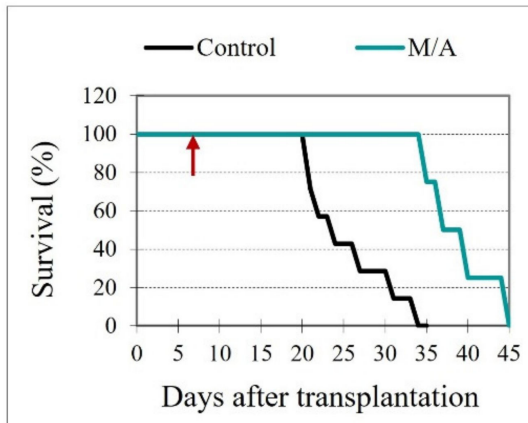

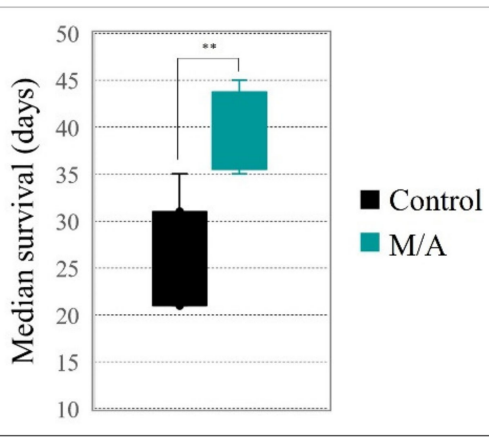

G

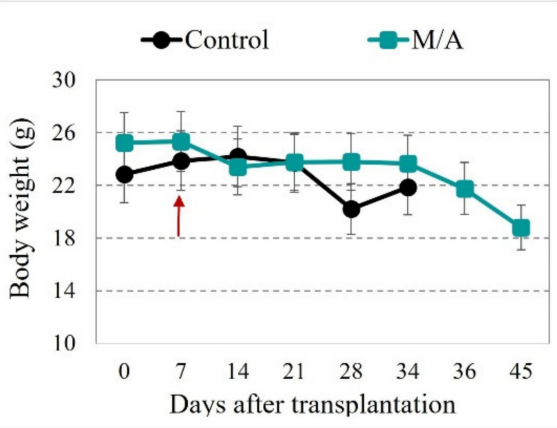

$\mathrm{H}$

\begin{tabular}{|l|l|l|}
\hline Parameter & Before M/A & After M/A \\
\hline $\begin{array}{l}\text { Hemoglobin } \\
(\mathrm{g} / \mathrm{dl})\end{array}$ & $14.7 \pm 0.9$ & $14.7 \pm 1.6$ \\
\hline $\begin{array}{l}\text { Hematocrit } \\
(\%)\end{array}$ & $43.7 \pm 2.7$ & $44.3 \pm 4.2$ \\
\hline $\begin{array}{l}\text { PT* } \\
(\mathrm{INR})\end{array}$ & $0.88 \pm 0.10$ & $0.90 \pm 0.96$ \\
\hline
\end{tabular}

I

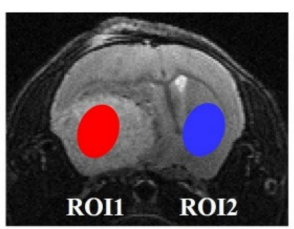

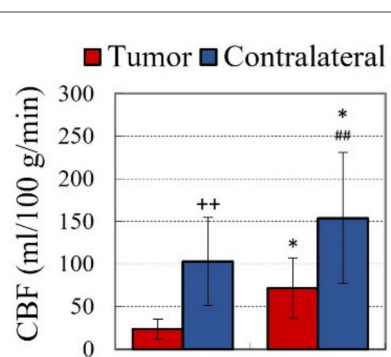

$\mathrm{K}$

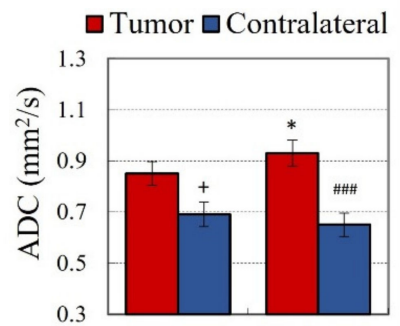

Figure 1. (A) Effect of single intracranial injection $(5 \mu \mathrm{L})$ of menadione/ascorbate $(\mathrm{M} / \mathrm{A})$ on tumor growth in the brain of U87MG glioblastoma-grafted mice, detected by $\mathrm{T}_{2}$-weighted magnetic resonance imaging (MRI) within 35 days after cell transplantation and 28 days after drug administration (70 $\mu \mathrm{g} / 7 \mathrm{mg}$ of $\mathrm{M} / \mathrm{A}$ per $\mathrm{kg}$ body weight). The drug was administered on day 7 of the brain cell transplant, when the tumor size was $14.17 \pm 4.5 \mathrm{~mm}^{3}$ in the control group and $22.0 \pm 6.4 \mathrm{~mm}^{3}$ in the M/A-treated group. Number of mice in each experimental group: control group $(n=7)$; M/A-treated group $(n=5)$. Data are the mean \pm SD from 3 mice at each time point. (B) Comparison of tumor size between control group and M/A-treated group, measured 3 weeks after intracranial injection of saline solution or $\mathrm{M} / \mathrm{A}$ injection ( ${ }^{* * *} p<0.001$ versus control group). (C) Comparison of tumor size in the control group, detected before and 1 week after intracranial injection of saline solution $\left(^{* * *} p<0.001\right.$ versus before injection). (D) Comparison of tumor size in the $\mathrm{M} / \mathrm{A}$-treated group, detected before and 1 week after intracranial injection of M/A. (E) Effect of single intracranial injection of M/A on survival of U87MG glioblastoma-grafted mice. Red arrow indicates the time of injection (day 7 after cell transplantation). Data are the mean \pm SD from 7 mice in the control group and 5 mice in the M/A-treated group. (F) Median survival of mice in the groups described in (E) ${ }^{* *} p<0.01$ versus control group). Data are the mean \pm SD from 7 mice in the control group and 5 mice in the M/A-treated group. (G) Dynamics of body weight of control and M/A-treated glioblastoma-grafted mice. Red arrow 
indicates the time of injection (day 7 after cell transplantation). At each time point, the data are the mean \pm SD from 2-7 mice in the control group and 2-5 mice in the M/A-treated group, depending on their survival. (H) Hematological parameters analyzed in healthy mice before and after intravenous administration of $\mathrm{M} / \mathrm{A}\left(140 \mu \mathrm{g} / 14 \mathrm{mg}\right.$ per $\mathrm{kg}$ body weight). ${ }^{*} \mathrm{INR}$-international normalized ratio (reference value $\leq 1.1$ ); PT-prothrombin time. Data are the mean \pm SD from 3 mice in each group with three measurements for each specimen in the case of $\mathrm{Hb}$ and $\mathrm{Hct}$, and six measurements for each specimen in the case of INR. (I-K) Multiparametric MRI analysis in M/A-treated and untreated glioblastoma mice (U87MG intracranial model). (I) Definition of regions of interest (tumor area and contralateral hemisphere). (J) Effect of M/A on cerebral perfusion (cerebral blood flow, CBF) and (K) apparent diffusion coefficient (ADC). Absolute values of $\mathrm{CBF}$ and $\mathrm{ADC}$ were detected in the tumor area and contralateral hemisphere of the brain. Both parameters were analyzed 21 days after cell transplantation and 14 days after drug administration. Data are the mean \pm SD from 3 mice in each group with two measurements (slices) per mouse. ${ }^{*} p<0.05, \mathrm{M} / \mathrm{A}$-treated tumor or contralateral hemisphere versus subsequent untreated (control) tumor or contralateral hemisphere; ${ }^{++} p<0.01$ for $\mathrm{CBF}$ and ${ }^{+} p<0.05$ for ADC, contralateral hemisphere versus tumor hemisphere in untreated mice; $\#$ \# $p<0.01$ for CBF and ${ }^{\# \# \#} p<0.001$ for ADC, contralateral hemisphere versus tumor hemisphere in $\mathrm{M} / \mathrm{A}$-treated mice.

\subsection{Effect of M/A on Tissue Redox State of Glioblastoma-Bearing Mice}

The tissue redox state was analyzed and visualized by the dynamic nitroxide-enhanced MRI before and after intravenous administration of multi-spin mito-TEMPO as a redoxsensitive probe. Mito-TEMPO penetrates the blood-brain barrier and cell membrane and is localized mainly in the mitochondria [66]. Three ROIs were selected in the glioma-bearing mice: (i) the tumor area in the brain (ROI1); (ii) the contralateral non-cancerous hemisphere (ROI2); and (iii) the surrounding (non-brain) tissues (ROI3) (Figure 2A). ROI2 and ROI3 were selected for comparison in untreated healthy mice. In glioblastoma mice, the signal intensity was high and long lived in the tumor area and non-brain surrounding tissues (Figure 2A-color image). In healthy mice, the nitroxide-enhanced MRI signal disappeared within 5 min after the injection of the nitroxide probe (Figure 2A-color image).

The kinetic curves of the normalized MRI signals in the respective ROIs are shown in Figure 2B-D. In healthy mice, the signal increased after the injection of the nitroxide probe, followed by a rapid decrease to the baseline in both ROIs (Figure 2C,D-gray curves). The enhancement of the MRI signal in the beginning is due to the presence of a nitroxide radical in the bloodstream and its penetration and accumulation in the subsequent tissue, whereas the decrease is due to its reduction to non-contrast hydroxylamine, which occurs predominantly in cells. In this case, the half-life of the nitroxide-enhanced MRI signal $\left(\tau_{1 / 2}\right)$ was approximately $80 \mathrm{~s}$, and the duration of the signal was approximately $5-6 \mathrm{~min}$ (Figure 2D-gray curves). The profile of the histograms indicates a high reducing capacity of healthy tissues for the nitroxide probe.

In glioblastoma-bearing mice, the nitroxide-enhanced MRI signal in the tumor (Figure 2B) and other ROIs (Figure 2C,D) had completely different kinetics than in healthy mice. The signal increased after injection and then reached a plateau without a decrease to the baseline within $14 \mathrm{~min}$. The signal intensity was significantly higher in the tumor area than in the contralateral hemisphere (Figure 2B,C). A high nitroxide-enhanced MRI signal was also found in the non-brain tissues that are located relatively far from the primary tumor locus (Figure 2D-black and green curves). The histograms indicate a high oxidative activity in the tumor and non-tumor tissues of the glioblastoma-bearing mice.

The integrated areas under the curves are shown in Figure 2E-G. Tissue oxidative activity in glioblastoma-bearing mice (M/A treated and untreated) was significantly higher than in healthy mice. $\mathrm{M} / \mathrm{A}$ treatment led to a further increase in oxidative activity in the tumor tissue, but remarkably not in the contralateral hemisphere. Rather, M/A treatment decreased the oxidative activity in the non-brain tissues of glioblastoma-bearing mice. 

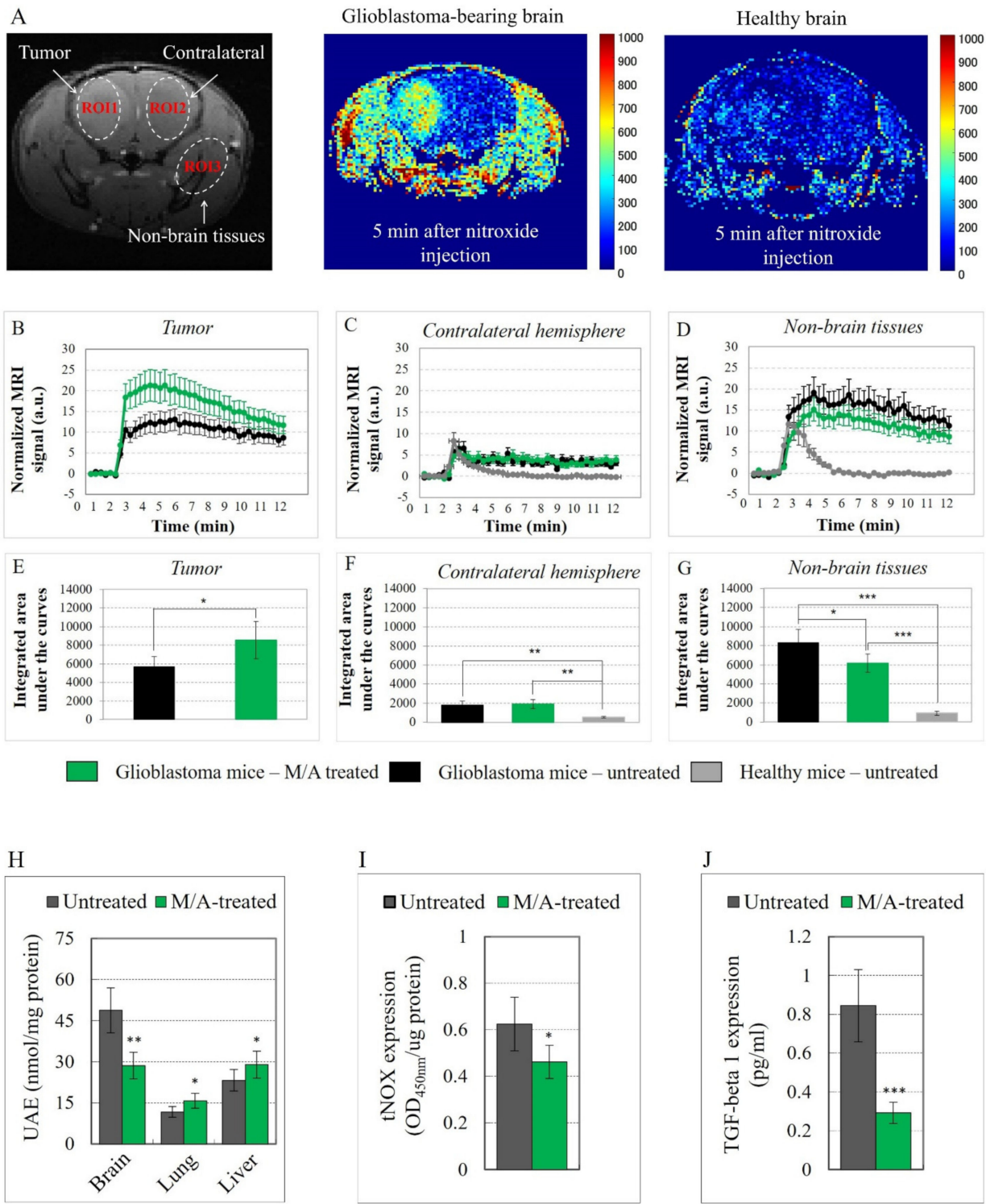

Figure 2. Redox imaging in glioblastoma-bearing mice using nitroxide-enhanced MRI. (A) Definition of regions of interest (ROIs): ROI1—tumor area; ROI2-contralateral hemisphere; ROI3—non-brain tissues (black and white image), and representative nitroxide-enhanced magnetic resonance images of glioblastoma-bearing brain and healthy brain, obtained $5 \mathrm{~min}$ after intravenous injection of nitroxide probe (mito-TEMPO) - a marker of tissue redox activity (color images). Color images—calculated extracted MRI signal obtained after injection of nitroxide probe and normalized to the baseline (native) signal obtained before injection. (B-D) Kinetic curves of nitroxide-enhanced MRI signal in U87MG glioblastoma-grafted mice (M/A treated and untreated) and healthy untreated mice. Kinetic curves were analyzed 7 and 14 days after drug administration. Data are the mean \pm SD from 6 mice in each group. (G-I) Integrated areas under the kinetic curves shown in D, E, and F, respectively. ${ }^{*} p<0.05,{ }^{* *} p<0.01,{ }^{* * *} p<0.001$. (H) Total reducing capacity of tissues isolated from untreated and M/A-treated glioblastoma-bearing mice. (I,J) Expression of tNOX (I) and TGF- $\beta 1(\mathbf{J})$ in the brain tissue and serum, respectively, isolated from untreated and $\mathrm{M} / \mathrm{A}$-treated glioblastoma-bearing mice. In (B-G), data are the mean \pm SD from 3 mice in each group with three measurements (slices) per mouse. In ( $\mathbf{H}-\mathbf{J})$, data are the mean \pm SD from 3 mice in each group with three measurements for each specimen. Tissue and blood specimens were collected 1 week after the start of $\mathrm{M} / \mathrm{A}$ administration and 2 weeks after cell transplantation. Treatment of mice was the same as described in Figure 1. ${ }^{*} p<0.05,{ }^{* *} p<0.01,{ }^{* * *} p<0.001$ versus the untreated group. 
We also analyzed tissue total redox capacity (TRC) ex vivo in the brain, as well as in other organs distant from the primary tumor locus-liver and lungs-isolated from $\mathrm{M} / \mathrm{A}$-treated and untreated glioblastoma-bearing mice (Figure $2 \mathrm{H}$ ). The results correlate with those of the redox imaging in vivo. The TRC of the brain tissues of M/A-treated mice was $\sim 40 \%$ lower compared to the untreated controls, while the liver and lung tissues of M/A-treated mice were characterized by a $\sim 20 \%$ higher reducing capacity compared to the untreated glioblastoma mice. This is indirect evidence that M/A increases the level of oxidative stress in tumor tissue but decreases the level of oxidative stress in healthy tissues of glioblastoma mice.

$\mathrm{M} / \mathrm{A}$ treatment of glioblastoma mice also resulted in a slight but significant decrease in tNOX expression in the brain tissues (Figure $2 \mathrm{I})$, and a strong decrease ( $\sim 3$-fold) in TGF- $\beta 1$ release in the blood (Figure 2J).

\subsection{Effect of $M / A$ on Mitochondrial Functionality, tNOX Expression, and Prenylation}

We compared the effects of $\mathrm{M} / \mathrm{A}$ treatment on the viability and redox homeostasis of isolated human glioblastoma cells (U87MG) and normal microglial cells (EOC2) (Figure 3). Cells were treated with different concentrations of $\mathrm{M} / \mathrm{A}$ for 24,48 , and $72 \mathrm{~h}$, and cell proliferation and viability were analyzed (Figure 3A,B). M/A was applied at low/tolerable concentrations $(<5 / 500 \mu \mathrm{M} / \mu \mathrm{M})$ and high concentrations $(\geq 5 / 500 \mu \mathrm{M} / \mu \mathrm{M})$. At concentrations $<5 / 500 \mu \mathrm{M} / \mu \mathrm{M}, \mathrm{M} / \mathrm{A}$ suppresses cell proliferation without inducing cell death, while at concentrations $\geq 5 / 500 \mu \mathrm{M} / \mu \mathrm{M}, \mathrm{M} / \mathrm{A}$ induces cell death, which has been demonstrated in vitro on cancer cell lines other than glioblastoma [46,67-69].

In normal microglial cells, M/A did not affect cell viability up to $20 / 2000 \mu \mathrm{M} / \mu \mathrm{M}$ (Figure 3B). In glioblastoma cells, $\mathrm{M} / \mathrm{A}$ exhibited a strong cytotoxicity at concentrations $\geq 5 / 500 \mu \mathrm{M} / \mu \mathrm{M}$, with an $\mathrm{IC}_{50}$ value of $\sim 8 / 800 \mu \mathrm{M} / \mu \mathrm{M}$ (Figure $3 \mathrm{~A}$ ). At low /tolerable concentrations $(2 / 200$ and $3 / 300 \mu \mathrm{M} / \mu \mathrm{M}), \mathrm{M} / \mathrm{A}$ markedly suppressed cell proliferation without significant cell death. The selective cytotoxicity of $\mathrm{M} / \mathrm{A}$ on glioblastoma cells only was also confirmed by the expression of PSer on the cell surface as a marker for induction of apoptosis (Figure 3C-blue columns versus red columns). The combination induced dosedependent overproduction of mitochondrial superoxide in glioblastoma cells -5 to 8 times above the level in untreated cells (Figure 3D, blue columns). In normal microglial cells, $\mathrm{M} / \mathrm{A}$ induced a relatively low increase in mitochondrial superoxide and mild oxidative stress, which seems to be well tolerated (Figure 3D, red columns). The comparative analysis showed that M/A exhibits selective cytotoxicity towards glioblastoma cells without significantly affecting the viability of normal microglial cells. This targeted cytotoxic effect of $\mathrm{M} / \mathrm{A}$ was accompanied by induction of severe oxidative stress in glioblastoma cells only.

$\mathrm{M} / \mathrm{A}$ treatment of glioblastoma cells induced a significant dose-dependent decrease in the values of the parameters characterizing mitochondrial functionality and cellular redox homeostasis: mitochondrial membrane potential, $\mathrm{NADH}, \mathrm{NAD}^{+}$, oncometabolite succinate, steady-state ATP amount, total intracellular glutathione, total cellular reducing capacity, and tNOX (Figure 3E). These parameters were not analyzed in M/A-treated normal microglial cells, as M/A did not affect the viability of these cells at the concentrations used and did not induce apoptosis, and the effect on mitochondrial superoxide was negligible (Figure 3B-D—red columns). An interesting finding was that cerivastatin-a specific inhibitor of mevalonate pathways and a non-specific prenyltransferase inhibitor [70]potentiated the cytotoxic effect of $\mathrm{M} / \mathrm{A}$ on glioblastoma cells but compromised the safety of $\mathrm{M} / \mathrm{A}$ on normal microglial cells, inducing significant cytotoxicity in these cells when combined with M/A (Figure 3F). This suggests that the prenylation of menadione and/or key proteins in the cells is essential for the targeted anticancer effect of the M/A combination, which is discussed below. 
A

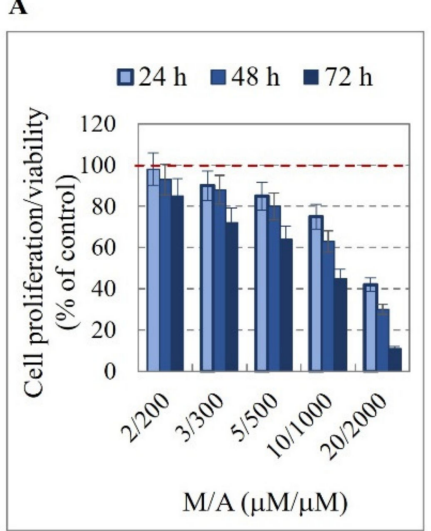

B

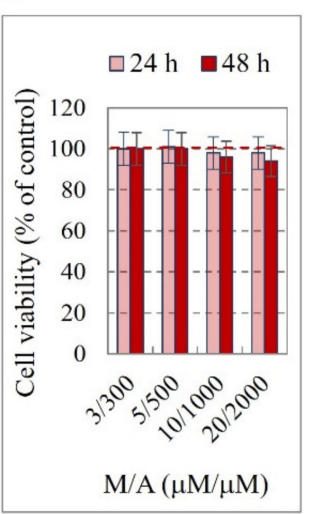

C

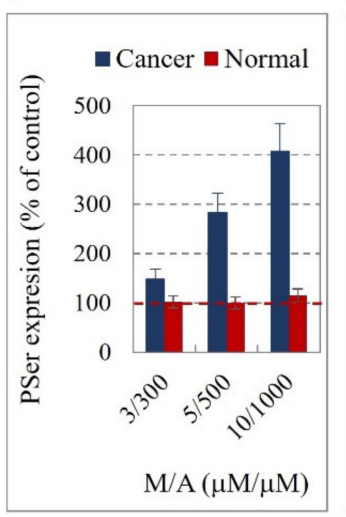

D

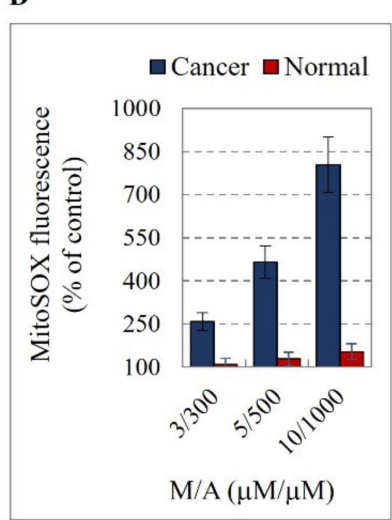

F

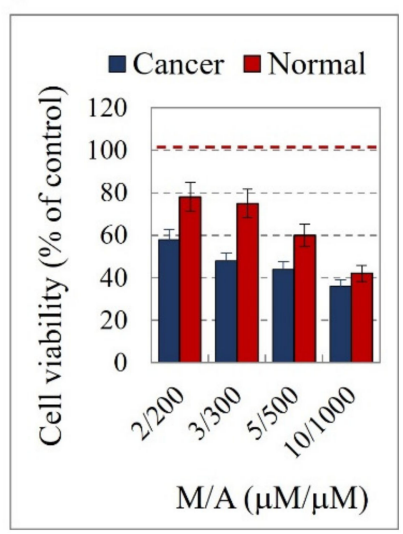

E

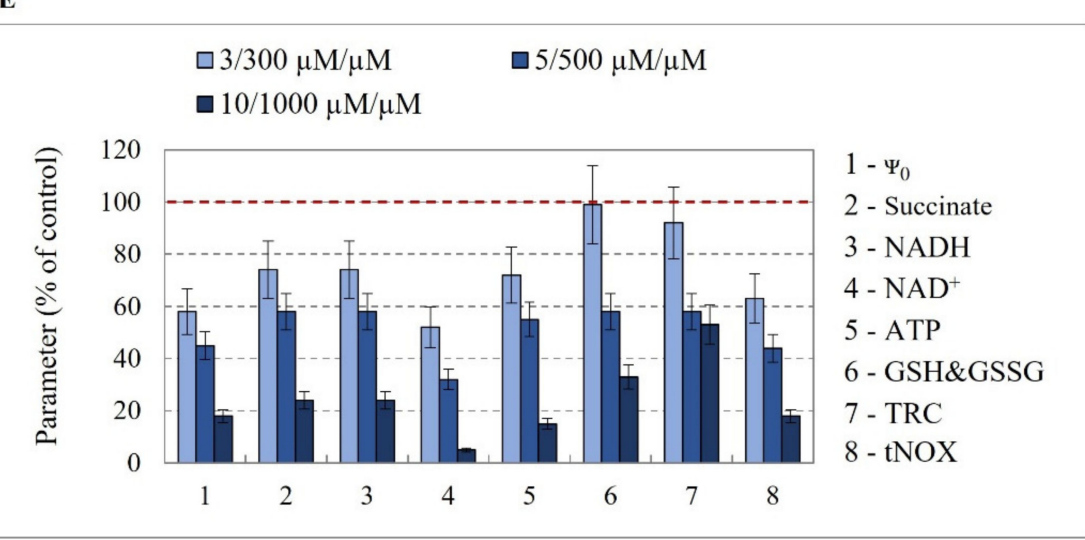

Figure 3. Effects of menadione/ascorbate $(\mathrm{M} / \mathrm{A})$ on mitochondrial and cellular redox state and viability. (A) Concentration-dependent and time-dependent effects of $\mathrm{M} / \mathrm{A}$ on proliferation and viability of glioblastoma cells (U87MG). (B) Concentration-dependent and time-dependent effects of $\mathrm{M} / \mathrm{A}$ on viability of normal microglial cells (EOC2). (C) Concentration-dependent effect of M/A on the induction of apoptosis in glioblastoma (blue columns) and normal microglial cells (red columns) after $48 \mathrm{~h}$ of incubation. (D) Concentration-dependent effects of M/A on steady-state levels of mitochondrial superoxide in normal (red columns) and glioblastoma cells (blue columns), analyzed after $48 \mathrm{~h}$ of incubation in humidified atmosphere. (E) Concentration-dependent effects of M/A on parameters representative of mitochondrial and cellular redox homeostasis: mitochondrial membrane potential $\left(\psi_{0}\right)$, succinate, NADH, NAD ${ }^{+}$, total glutathione (GSH and GSSG), total reducing capacity (TRC), and tumor-associated NADH oxidase (tNOX). All parameters were analyzed after incubation of glioblastoma cells (U87MG) with M/A for $48 \mathrm{~h}$ in humidified atmosphere. (F) Effect of cerivastatin $(5 \mu \mathrm{M})$ on viability of M/A-treated glioblastoma cells (U87MG) and normal microglial cells (EOC2) after $48 \mathrm{~h}$ of incubation. The cells in the control sample were treated with cerivastatin only. The initial number of cells in all samples was $0.6 \times 10^{5}$ cells per well. Data are the mean \pm SD from three independent experiments with two parallel measurements for each experiment in (A-D,F), and two independent experiments with four parallel measurements for each experiment in (E). In all charts, the value of each parameter in the untreated (control) samples was considered as $100 \%$ (red dashed lines). All differences exceeding 15\% were statistically significant.

\section{Discussion}

Summarizing, our study demonstrates that the redox pair "menadione/ascorbate" inhibited the growth and viability of glioblastoma cells and tissues without adversely affecting the viability of normal cells and tissues at pharmacologically achievable concentrations. These findings were obtained in vivo on glioblastoma mice (Figures 1 and 2) and in vitro on cultured cells (Figure 3). 
A single intracranial injection of $\mathrm{M} / \mathrm{A}(70 \mu \mathrm{g} / 7 \mathrm{mg}$ per $\mathrm{kg}$ body weight) in glioblastoma mice and subsequent oral administration in the drinking water ( $15 \mathrm{~g} / 150 \mathrm{mg}$ per liter) significantly increased survival without adverse drug-related side effects (Figure 1E).

Tissues (cancerous and healthy) of glioblastoma mice were characterized by a higher oxidative capacity than tissues of healthy mice (Figure 2A-I). M/A treatment significantly increased oxidative stress and decreased the reducing capacity of the tumor tissue (Figure 2B,E) but did not affect the redox state of healthy brain tissues (Figure 2C,F). Furthermore, $\mathrm{M} / \mathrm{A}$ treatment decreased oxidative stress in non-brain tissues distant from the primary tumor (such as liver and lung tissue) and increased their reducing capacity (Figure 2D,G).

M/A treatment inhibited the expression of TGF- $\beta 1$ (Figure 2J) and tNOX in the glioblastoma mice (Figure 2I).

$\mathrm{M} / \mathrm{A}$ treatment decreased the cell density (evaluated by ADC) in the tumor tissue but not in non-tumor brain tissues (Figure $1 \mathrm{~K}$ ) and increased perfusion (evaluated by $\mathrm{CBF}$ ) markedly in the tumor and slightly in the non-tumor brain tissues (Figure 1J).

$\mathrm{M} / \mathrm{A}$ induced cytotoxicity and apoptosis in isolated glioblastoma cells but not in normal microglial cells (Figure $3 \mathrm{~A}-\mathrm{C}$ ). This effect was accompanied by dose-dependent overproduction of mitochondrial superoxide in glioblastoma cells only (Figure 3D), as well as by a dose-dependent decrease in the levels of the following parameters: mitochondrial membrane potential, $\mathrm{NADH}, \mathrm{NAD}^{+}$, succinate, steady-state ATP, intracellular glutathione, total cellular reducing capacity, and tNOX (Figure 3E). This indicates an impairment of the mitochondrial function and cellular redox homeostasis of glioblastoma cells.

The above observations suggest that M/A may differentiate cancer cells and tissues from healthy ones. Thus, the drug causes oxidative stress only in the tumor, evaluated by redox imaging using MRI in vivo and the TRC assay ex vivo. It does not adversely affect the redox state in healthy tissues (such as lung and liver tissue) and may even suppress oxidative stress in them (Figure 2H). The TRC assay, also called the "Total Antioxidant Capacity Assay", used in our study provides partial information on the antioxidant status in cells and tissues. The study of the effects of M/A on the state of various endogenous antioxidants and pro-oxidants would help to elucidate the fine molecular mechanism(s) of its redox-modulating effect.

We also found that M/A treatment does not cause hemolysis, erythropenia, and thrombosis at the selected doses (Figure 1H). The harmless and even beneficial effects of $\mathrm{M} / \mathrm{A}$ on normal cells and healthy tissues may be one of the reasons for the good tolerance to the drug.

A few articles have described the effect of menadione and ascorbate on the viability of glioma/glioblastoma cells in vitro. Menadione alone and in combination with ascorbate has been shown to significantly inhibit DNA replication and the growth of patient-derived glioma cells [57]. The authors reported that M/A completely inhibited the re-growth of glioma cells at long-term treatment in vitro, while menadione-treated cells resumed their proliferation. Ascorbate administered alone in tolerable doses $(\leq 2.5 \mathrm{mM})$ did not suppress the growth of human glioma cells [57]. However, high doses of ascorbate $(\geq 5 \mathrm{mM})$ significantly increased intracellular ROS and decreased the proliferation of human glioma cells, causing necrotic cell death [71]. Intravenous administration of ascorbate $(1 \mathrm{~g}$ and $2 \mathrm{~g}$ per $\mathrm{kg}$ body weight) to glioblastoma-bearing rats inhibited tumor growth and invasion, analyzed ex vivo [71]. It should be noted that the risk of adverse side effects is potentially high at these doses of ascorbate, according to the literature [72-74]. Recently, it has been reported that pharmacological ascorbate has a radio-protective effect on glioma-bearing mice (GL261 intracranial model) [75]. The authors found that tumor growth was faster, and survival was shorter, in mice treated with 6 Gy radiation plus ascorbate versus those treated with 6 Gy radiation alone. It is obvious that menadione and ascorbate, administered alone, do not have the power of the anticancer effect of their combination in glioma/glioblastoma cells and tissues. Studies on experimental animals have reported that oral and parenteral M/A potentiates the efficiency of conventional chemotherapy and radiotherapy of cancer in vivo 
and inhibits invasion and metastasis [76-80]. This suggests that the molecular mechanisms of action of the $\mathrm{M} / \mathrm{A}$ combination are different from those of ascorbate administered alone.

Menadione and ascorbate are powerful redox cyclers and, when administered alone and especially in combination, induce intracellular production of ROS by interaction with molecular oxygen $[46,81,82]$. It is generally accepted that M/A causes cancer cell death by induction of oxidative stress and subsequent replicative stress [67-69]. This mechanism has also been described in M/A-treated glioma cells in vitro [57]. However, it does not explain the selective cytotoxicity of $\mathrm{M} / \mathrm{A}$ towards cancer cells only or the possible role in the immune system

We propose another potential mechanism for the selective targeting of cancer cells by M/A (Figure 4). Cancer cells, including glioblastoma cells, differ significantly from normal cells in several characteristics. Cancer cells have overexpressed ascorbate transporters (GLUT1, SVCT1, and SVCT2) [56], which allows the accumulation of much higher concentrations of ascorbate in them compared to normal cells. Cancer cells are overloaded with reducing equivalents, such as NADH and succinate, and their mitochondria are overcharged due to the high $\mathrm{CoQ} 10 \mathrm{H}_{2} / \mathrm{CoQ} 10$ ratio $[24,52,53,83,84]$. This allows a highly specific and accelerated redox cycling of $\mathrm{M} / \mathrm{A}$ in dysfunctional cancerous mitochondria, but not in normally functioning mitochondria. Normal cells express UbiA prenyltransferase domain containing protein 1 (UBIAD1), also known as transitional epithelial response protein 1 (TERE1), which converts menadione to vitamin K2 [85,86]. Recently, we established that the combination vitamin $\mathrm{K} 2$ /ascorbate $(\leq 20 / 2000 \mu \mathrm{M} / \mu \mathrm{M})$ has a negligible effect on cell viability [46]. However, down-regulation of UBIAD1 is a hallmark of multiple cancers, according to the Human Protein Atlas [87], and this prenyltransferase is one of the newest prognostic markers discussed in cancer, according to recent cohort studies [87-89]. The conversion of menadione to vitamin K2 should be suppressed in cancer cells due to down-regulation of UBIAD1. Thus, cancer cells should accumulate high concentrations of menadione/ascorbate, while normal cells should contain a vitamin K2/ascorbate combination. In our study, we found that the safety of $\mathrm{M} / \mathrm{A}$ on normal cells was compromised by treatment with cerivastatin, a specific inhibitor of mevalonate pathways and a non-specific prenyltransferase inhibitor (Figure 3F). This is indirect evidence that UBIAD1 could be a key factor in the selective cytotoxicity of M/A to cancer cells, and this is the subject of ongoing study in our team.

CANCER-BEARING
ORGANISM
SUPPRESSION OF
DRUG RESISTANCE
$\downarrow$ tNOX
$\downarrow$ TGF- $\beta 1$
SUPPRESSION OF
TUMOR INVASION
Decreased oxidative stress
in "normal tissues"

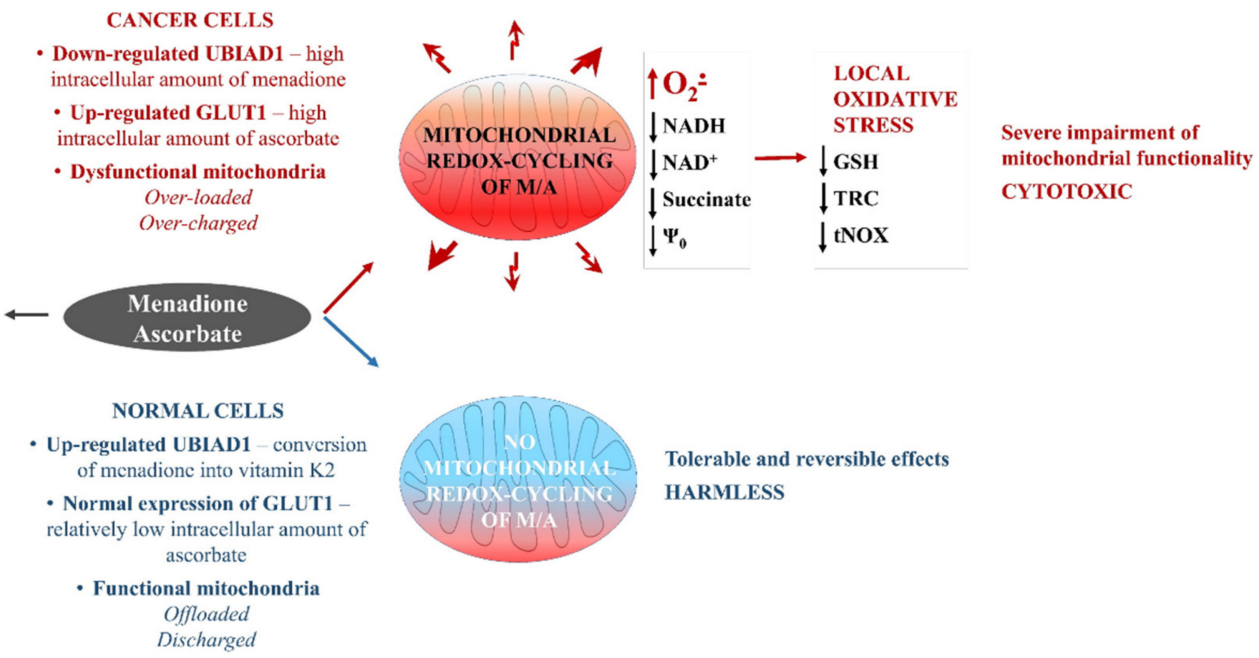

Figure 4. Potential molecular mechanism(s) for selective targeting of cancer cells by M/A via specific redox cycling in the overloaded and overcharged cancerous mitochondria due to down-regulation of UBIAD1 and inhibition of menadione prenylation, and up-regulation of vitamin $C$ transporters in cancer cells. Role of tNOX and TGF- $\beta 1$ in M/A-mediated anticancer effect on cancer-bearing organisms. 
UBIAD1/TERE1 is known as a tumor suppressor gene [85-89]. Down-regulation of UBIAD1 has been shown to activate Ras-MAPK signaling [90], one of the main signaling networks in gliomas [91]. UBIAD1 is also involved in the regulation of cholesterol levels via steroid and xenobiotic receptor (SXR) target genes, as well as the synthesis of ubiquinones [92,93]-decisive factors in inducing carcinogenesis and survival of cancer cells.

Another possible mechanism of action of $\mathrm{M} / \mathrm{A}$ in glioblastoma could be related to the effect of ascorbate on histone methylation. Vitamin $\mathrm{C}$ has been found to play a pivotal role in remodeling the epigenome by enhancing the activity of Jumonji-C domain-containing histone demethylases (JHDMs) and the ten-eleven translocation (TET) proteins [94]. The ability of vitamin $C$ to potentiate the activity of histones and DNA-demethylating enzymes has clinical application in the treatment of cancer. Vitamin C deficiency has been widely reported in cancer patients and has been shown to accelerate cancer progression in animal models [94]. However, it should be noted that the effect of vitamin $\mathrm{C}$ on demethylation of histones may antagonize the anticancer effect of DNA-alkylating drugs, such as temozolomide. MGMT promoter methylation is the key mechanism of MGMT gene silencing and predicts a favorable outcome in patients with glioblastoma who are exposed to alkylating agent chemotherapy $[95,96]$. We found that M/A did not abolish or decrease the cytotoxic effect of temozolomide in isolated glioblastoma cells (Figure S4, see the Supporting Materials). There was a very slight potentiation of the cytotoxicity of temozolomide at low/tolerable concentrations of $\mathrm{M} / \mathrm{A}$, but not at high concentrations. This indicates that the effect of ascorbate (when it is in combination with menadione) on histone demethylation is not critical for the anticancer effect of temozolomide.

Based on these factors, we assume that the targeted anticancer effect of $\mathrm{M} / \mathrm{A}$ is due to its specific redox cycling in the dysfunctional mitochondria of cancer cells only, which is accompanied by severe oxidative stress and an impairment of their "pro-oncogenic" functionality. This mechanism appears to be valid for glioblastoma. M/A treatment of isolated glioblastoma cells decreased their over-reduced state (decrease in NADH, succinate, glutathione, etc.) and mitochondrial membrane potential, which was accompanied by overproduction of mitochondrial superoxide (Figure 3D,E). We assume that in normal cells, there is no such mitochondrial redox cycling between the two substances and the effects of $\mathrm{M} / \mathrm{A}$ are tolerable and reversible (Figure 4). Our in vivo data support this hypothesis. $\mathrm{M} / \mathrm{A}$ treatment of glioblastoma-bearing mice induced severe oxidative stress in the tumor tissue, but not in the non-tumor tissues (Figure $2 \mathrm{~A}-\mathrm{G}$ ).

The mechanism of glioblastoma targeting by $\mathrm{M} / \mathrm{A}$ is complex and likely not limited simply to modulating the redox state and overproduction of ROS in cancer cells and tissues. The decreased expression of tNOX and TGF- $\beta 1$ (Figure 2I,J) and the decreased production of the oncometabolite succinate (Figure 3E) in M/A-treated animals suggest an influence of the immune response. The expression and activity of $t$ NOX have been shown to have a direct effect on the immune response in cancer. Recently, Hsieh et al. administered an anti-tNOX vaccine to mice with lung cancer [97]. The authors reported that vaccinated mice showed significantly less tumor mass and a significantly lower histological outcome of the lesion. They concluded that tNOX has an immunogenic effect, and that the tNOX vaccine has potential in the immunotherapy of lung cancer. However, it should be noted that the effect of the tNOX vaccine on tumor growth is modest. The cytokine TGF- $\beta$ also plays a crucial role in regulating the immune response and cancer progression, which is sufficiently described in two recent review articles $[98,99]$. TGF- $\beta$ exerts systemic immune suppression and inhibits the recognition of cancer cells by the host immune system. Suppression of TGF- $\beta$ expression or inhibition of its conversion from the latent to the active state leads to: (i) an increased anticancer immune response mediated by CD8+ T cells and natural killer cells; (ii) increased neutrophil-attracting chemokines, resulting in recruitment and activation of neutrophils with an anticancer phenotype. This cytokine regulates the infiltration of inflammatory/immune cells and cancer-associated fibroblasts in the tumor microenvironment, causing direct changes in cancer cells. TGF- $\beta$ has been shown 
to directly affect PD-1 expression on T cells and PD-L1 expression on cancer cells, which suppresses the anticancer activity of the native immune system [100]. Another important immunomodulator is the oncometabolite succinate, which was sufficiently analyzed and described by Ryan et al. in the context of carcinogenesis [101].

$\mathrm{tNOX}$ is a hydroquinone (NADH) oxidase that serves as a terminal oxidase in a process whereby protons and electrons are shuttled from the inside of the cell across the cell membrane to molecular oxygen at the cell surface (plasma membrane electron transport) [102]. Being located on the cell surface and without membrane anchoring domains, the protein is released from the cells and appears in the serum and urine as a relatively stable and readily accessible biofluid marker [103]. tNOX is a molecule involved in the hallmarks of cancer cells, down-regulated in slow-proliferating non-cancer cells, and currently undiscovered in non-proliferating normal cells [26,27,102]. Thus, suppression of tNOX with anticancer drugs could selectively inhibit cell growth and induce apoptosis in cancer cells, but not in normal cells [103-107]. Some conventional anticancer drugs have been shown to transiently up-regulate tNOX expression, thereby enhancing the migration of cancer cells and causing the development of drug resistance $[107,108]$. Inhibition of tNOX expression/activity has been recently reported to affect mitochondrial function by decreasing $\mathrm{NAD}^{+}$-dependent SIRT1 deacetylase activity and increasing acetylation of p53, which causes augmentation of ROS-dependent mitochondrial autophagia and induces apoptosis in cancer cells [103-106]. The down-regulation of tNOX and the decreased $\mathrm{NADH}$ and $\mathrm{NAD}^{+}$levels in $\mathrm{M} / \mathrm{A}$-treated glioblastoma cells and tissues observed in our study (Figures 2I and 3E) are indirect evidence that this mechanism could be important in glioblastoma. In this context, tNOX could be a valuable therapeutic target, distinguishing cancer cells from normal cells and enabling selective damage of cancerous mitochondria. tNOX could also maintain the level of the quinone form of the menadione required for the intracellular redox cycling with ascorbate in cancerous mitochondria.

TGF- $\beta$ is another molecular target in glioblastoma, whose expression was strongly suppressed in M/A-treated mice (Figure $2 \mathrm{~J}$ ). In general, TGF- $\beta$ has a complex role in carcinogenesis including cancer cell motility and metastasis, proliferation of tumor-associated fibroblasts, epithelial-to-mesenchymal transition, angiogenesis, and immunosuppression [109]. TGF- $\beta$ is responsible for the spread of inflammation, and its expression in glioblastomabearing mice may explain, at least partially, the high oxidative capacity of healthy tissues distant from the primary tumor locus (Figure 2D,G). The spread of inflammation is always associated with the spread of ROS generation and oxidative stress [24,110]. Other proinflammatory cytokines (TNF-alpha, IL-2, IL-12, etc.) are also of great interest as therapeutic targets for cancer [111] that could be affected by M/A. However, this hypothesis needs verification.

What could be the possible mechanism of the spread of inflammation far from the primary tumor and the effect of $\mathrm{M} / \mathrm{A}$ treatment?

Transplantation of cancer cells in the brain can be considered an "inflammatory signal" [112]. The xenograft leads to a local migration and an activation of a wide variety of immune cells in the target tissue, especially in the microenvironment of the primary transplant. This activation may trigger redox imbalance due to the "oxidative burst" of the immune cells and the production and release of ROS in the grafted area. In turn, ROS could provoke signal transduction in three targets with equal probability: (i) the grafted cancer cells, (ii) the surrounding normal cells, and (iii) the surrounding extracellular matrix. This activates the integrin signaling and modulates integrin function through conformational changes [113], which is usually associated with the activation of the latent proinflammatory and profibrotic cytokines, such as TGF- $\beta$, secreted in the tumor microenvironment [114]. De Bleser et al. reported that menadione $(12.5-50 \mu \mathrm{M})$ decreased TGF- $\beta$ expression by approximately 5-fold in rat hepatic cells, and this effect correlated with a low level of glutathione, which acts as a secondary messenger in the TGF- $\beta$ signal transduction pathway [115]. In our study, we observed that $M / A$ treatment of glioblastoma-bearing mice decreased the expression of TGF- $\beta 1$ by approximately 3 -fold compared to the untreated 
mice (Figure 2J), which is direct evidence of its anti-inflammatory effect and indirect evidence of its anti-fibrotic effect. However, M/A treatment causes a significant but not very severe decrease in the oxidative capacity and inflammation of the tissues far from the primary tumor (Figure 2D,G). This suggests that there are factors other than TGF- $\beta 1$ responsible for the spread of inflammation that are not affected by M/A. It should be noted that our study was conducted on $\mathrm{T}$ cell-immunodeficient mice, and the proinflammatory effects of TGF- $\beta$ are mediated by T cell immunity $[114,116]$. This could also explain why the strong inhibition of TGF- $\beta 1$ expression by M/A (Figure 2J) did not lead to an equally strong suppression of inflammation in the healthy tissues of our glioblastoma-bearing mice (Figure 2G). In our previous study, we demonstrated that M/A at doses achievable by oral administration significantly suppressed the expression of programmed death ligand 1 (PD-L1) in cancer cells [46]. This suggests that the anticancer effect of M/A is probably related to modulation of the immune response. PD-L1 is a transmembrane protein which is overexpressed in cancer cells and plays a major role in suppressing the adaptive immune response [117]. The PD-1/PD-L1 checkpoint pathway is one of the most promising targets of advanced cancer immunotherapy, including treatment of glioblastoma $[1,13,117,118]$. $\mathrm{M} / \mathrm{A}$ may potentiate the effectiveness of anticancer immunotherapy and suppress the development of drug resistance, which is worth exploring in the future.

Recent studies showed that succinate is also involved in the regulation of innate immunity, the spread of inflammation, and carcinogenesis [119,120]. We observed that M/A significantly decreased the level of succinate in glioblastoma cells (Figure 3E), suggesting a decrease in their malignancy and invasiveness, as well as an anti-inflammatory effect.

Studies on wild-type animals with non-brain tumor xenografts and an intact immune system have reported that oral and parenteral M/A potentiates the efficiency of conventional chemotherapy and radiotherapy, inhibits invasion and metastasis, and increases survival [76-80]. The weights of the spleen and thymus were found to be higher in M/Atreated animals compared with those receiving conventional drugs alone [76,77,79], which also suggests the involvement of mechanisms related to immune stimulation. Menadione and ascorbate, administered alone, manifest anti-inflammatory effects [121,122] that also contribute to suppression of cancer progression and invasion [123]. These studies suggest that M/A may have a beneficial effect on the immune system of cancer-bearing organisms, making the cancer cells more accessible, "visible", and perhaps more vulnerable to native immune cells. This hypothesis must be explored.

The MRI analysis of CBF and ADC provides further evidence of the versatile effects of $\mathrm{M} / \mathrm{A}$ and the complexity of its selective anticancer effect (Figure 1J,K).

$\mathrm{CBF}$ is a marker for vascular remodeling and tissue perfusion in brain disorders, including cancer [124,125]. Poor perfusion of brain tumors, combined with severe fibrosis, maintains their hypoxic and malignant behavior without disrupting the flow of essential metabolites required for cell proliferation and invasion. The interplay between glioblastoma and the surrounding microglial cells leads to endothelial dysfunction, endothelial-tomesenchymal transition, and neuroinflammation $[126,127]$. Suppression of neuroinflammation in normal brain tissue without affecting the recognition and elimination of cancer cells by the immune system is crucial to suppress glioblastoma invasion and metastasis and increase the effectiveness of conventional therapy. The access of anti-inflammatory agents to the brain and suppression of general neuroinflammation are tightly related to the cerebral blood flow. Our data demonstrate that in untreated mice, perfusion in the tumors, estimated by $\mathrm{CBF}$ values, was approximately four times lower than in the contralateral hemispheres $(p<0.01)$, but in M/A-treated mice, this difference was approximately two times lower $(p<0.05)$ (Figure 1J). M/A treatment of glioblastoma-bearing mice significantly increased perfusion in the tumor. Increased cerebral perfusion suggests that M/A could facilitate the penetration of conventional drugs into the tumor and potentiate their therapeutic effect. In vitro and in vivo studies have shown that M/A potentiates the efficiency of conventional chemotherapy and radiotherapy of cancer, which is often accompanied by 
synergistic cytotoxicity in cancer cells and suppression of tumor growth in vivo, as well as by inhibition of invasion and metastasis $[46,76,77,79]$.

$\mathrm{ADC}$ is a measure of the magnitude of water diffusion in tissues [61,62]. This parameter is sensitive to the cellular density and microenvironment of the tumor [128,129]. ADC negatively correlates with compact tumor structures, characterized by a high cell density due to the proliferation of cancer cells and a "tight" microenvironment composed of fibroblasts, immune cells, and other cellular components [129]. All these cellular factors restrict the diffusion of water in the tumor. In contrast, apoptotic or necrotic areas of tumors are characterized by elevated ADC values because of the decreased cellular density [130,131]. This makes ADC a potential non-invasive biomarker for monitoring and predicting the response to therapy $[129,131]$. In recent years, ADC has also been used to distinguish between malignant and benign lesions [132]. Our data demonstrate that M/A treatment of glioblastoma-bearing mice significantly increased ADC values in tumors $(\sim 15 \%)$ but did not affect the values in contralateral brain tissues (Figure 1K). These findings suggest that $\mathrm{M} / \mathrm{A}$ treatment decreases the cell density in the tumor and increases water diffusion, which is confirmed by histological data on M/A-treated animals published in the literature [133]. It was found that $\mathrm{M} / \mathrm{A}$ (at certain doses) causes apoptosis, ferroptosis, necrosis, and a specific form of cell death called autoschizis $[46,67,129,131,133]$. Autoschizis is characterized by a reduction in cell size due to loss of cytoplasm by self-excision without loss of cell organelles, morphological degradation of the nucleus, and formation of apoptotic bodies [133]. During the experiments, using light microscopy, we also noticed that the size of M/A-treated glioblastoma cells markedly decreased compared to that of untreated cells, even at low/tolerable concentrations of M/A [46]. This may explain, at least partially, the decreased cellular density in $\mathrm{M} / \mathrm{A}$-treated brain tumors in vivo.

A decreased size of $\mathrm{M}$ / A-treated cancer cells (described in autoschizis) and a decreased cellular density in the tumor lead to an increased flow of extracellular fluids in the tumor. Such changes are not observed in non-cancerous cells and tissues. Thus, drugs and immune cells can easily reach cancer cells in $\mathrm{M} / \mathrm{A}$-treated tumors without significantly altering healthy brain tissues. Drug-induced immunomodulation and concomitant inflammation should be tightly controlled in the brain during anticancer therapy and located only in the lesion, to avoid morphological changes in healthy brain tissue and neurological disorders. Future histological/cytological experiments clarifying the effect of $\mathrm{M} / \mathrm{A}$ on the level and functional state of tumor-associated macrophages and T cells can clarify the mechanism of $\mathrm{M} / \mathrm{A}$-mediated immunomodulation in glioblastoma.

\section{Conclusions}

In conclusion, our study describes a pharmacological strategy for selective targeting and treatment of glioblastoma using a redox-active combination drug, quinone/ascorbate (M/A). A single intracranial injection of $\mathrm{M} / \mathrm{A}$ in mice with brain glioblastoma, and subsequent daily oral administration in the drinking water, significantly suppressed tumor growth and increased survival without adverse drug-related side effects. This was accompanied by severe induction of oxidative stress in cancer tissue, but not in healthy tissues, an increase in cerebral perfusion in the tumor, and a decrease in its cellular density.

We believe that repeated intracranial injections of $\mathrm{M} / \mathrm{A}$ would stop the growth of the tumor and potentially make it operable. In a pilot study, we observed such an effect on hind paw-grafted glioblastoma mice, after three subcutaneous injections of M/A near the tumor. However, appropriate catheter system and neurosurgical procedure are needed to perform multiple intracranial injections or infusions of the drug to maintain intracranial pressure and ensure a normal brain function and a normal general condition. At present, this is difficult to achieve intracranially on small animals, but it seems possible on large animals and humans using an Ommaya reservoir.

Experimental data in vitro indicate that the mechanism of the anticancer effect of $\mathrm{M} / \mathrm{A}$ is related to: (i) selective impairment of cancerous mitochondria due to a specific redox cycling between the two molecules, accompanied by a significant decrease in their over- 
reduced state (NADH, succinate, glutathione, etc.), mitochondrial potential, and steadystate ATP, as well as overproduction of mitochondrial superoxide; (ii) down-regulation of tNOX and TGF- $\beta 1$, suggesting modulation of the immune response and a potential role in suppressing drug resistance.

In recent decades, we have learned that targeting a single enzyme or pathway rarely leads to successful cancer treatment. Specific redox targeting of cancer cells based on their altered mitochondrial bioenergetics and metabolism is emerging as a promising and safe new strategy for successful cancer therapy due to its universality in transformed cells (so-called "mitocan therapy") [134]. Altered mitochondrial function, characterized by their over-reduced (overcharged) Q-pools, and overloading with metabolites (such as succinate and NADH), is a prominent feature of all cancers and potentially a root cause of their proliferation and escape from the immune system. It appears that M/A can "recognize" altered mitochondria and selectively impair their "pro-oncogenic" functionality. This may alter T cell differentiation and/or "mark" cancer cells to make them more "visible" and "accessible" to the immune system and conventional therapies. Nature has selected these redox-active substances as essential during evolution (menadione (pro-vitamin K3) and ascorbate (vitamin C)). Perhaps their main non-vitamin function is to detect defective cells, to "mark" them by altering their redox homeostasis, and to facilitate mechanisms for their removal. In this context, safe redox-active compounds such as M/A and other quinone/ascorbate combinations, acting by the described redox-targeting mechanism, could significantly contribute to the success of therapy in glioblastoma, as well as other cancers. Defective mitochondria appear to be an "Achilles' heel" for the M/A combination and a major molecular target for its anticancer effect.

Supplementary Materials: The following supporting information can be downloaded at: https: / / www.mdpi.com/article/10.3390/cancers14030485/s1, Figure S1: Schematic representation of redox cycling of menadione with production of superoxide and hydrogen peroxide; Figure S2: Experimental design on glioblastoma mice; Figure S3: Microscopic detection of thrombosis before and after intravenous administration of $\mathrm{M}$ /in healthy mice; Figure S4: Concentration-dependent and time-dependent effects of M/A on proliferation and viability of temozolomide-treated glioblastoma cells; Table S1: Redox therapies against glioblastoma.

Author Contributions: Conception and design: R.B., Z.Z. and T.M.; development of methodology: R.B., A.S., S.S. and D.L; acquisition of data (provided animals, acquired and managed patients, provided facilities, etc.): R.B. and I.A.; analysis and interpretation of data (e.g., statistical analysis, biostatistics, computational analysis): A.S., D.L. and R.B.; writing, review, and/or revision of the manuscript: R.B., Z.Z., A.S., I.A., T.M. and T.O.; administrative, technical, or material support (i.e., reporting or organizing data, constructing databases): I.A.; study supervision: T.H. All authors have read and agreed to the published version of the manuscript.

Funding: This study was partially supported by the following grants: QST/ICM grant funded by ICMedTech Corp., U.S. (granted to R.B.); AMED Grant Number $16 \mathrm{~cm} 0106202 \mathrm{~h}$ funded by the Japanese Agency for Medical Research and Development; and Kakenhi (\#21H04966, 21KK0201, 17KK0102) funded by the Japanese Agency for Promotion of Science. MRI devices were partly supported by the grant for promoting public utilization of advanced research infrastructure (\#JPMXS0450400422) funded by the JST/MEXT, Japan.

Institutional Review Board Statement: The animal experiments in this study were approved by the National Institutes for Quantum Science and Technology (QST) Institutional Animal Care and Use Committee, Chiba, Japan, and all experiments were performed in accordance with the relevant guidelines and regulations (protocol No 14-1006).

Informed Consent Statement: Not applicable.

Data Availability Statement: Data are contained within the article.

Acknowledgments: The participation of Raj Parajuli (QST, Japan) and Megumi Iiyama (QST, Japan) in the MRI measurements is gratefully acknowledged.

Conflicts of Interest: The authors declare no conflict of interest. 


\section{References}

1. Bush, N.E.O.; Chang, S.M.; Berger, M.S. Current and Future Strategies for Treatment of Glioma. Neurosurg. Rev. 2017, 40, 1-14. [CrossRef] [PubMed]

2. Sampson, J.H.; Gunn, M.D.; Fecci, P.E.; Ashley, D.M. Brain Immunology and Immunotherapy in Brain Tumors. Nat. Rev. Cancer 2020, 20, 12-25. [CrossRef] [PubMed]

3. Patel, V.; Shah, J. The Current and Future Aspects of Glioblastoma: Immunotherapy a New Hope? Eur. J. Neurosci. 2021, 54, 5120-5142. [CrossRef] [PubMed]

4. Poon, M.T.C.; Sudlow, C.L.M.; Figueroa, J.D.; Brennan, P.M. Longer-Term (over 2 Years) Survival in Patients with Glioblastoma in Population-Based Studies Pre- and Post-2005: A Systematic Review and Meta-Analysis. Sci. Rep. 2020, 10, 11622. [CrossRef] [PubMed]

5. Femandes, C.; Costa, A.; Osorio, L.; Lago, R.C.; Lonhares, P.; Carvalho, B.; Caeiro, C. Current Standards of Care in Glioblastoma Therapy. In Glioblastoma; Chapter 11; De Vleeschouwer, S., Ed.; Codon Publ.: Brisbane, Australia, 2017; ISBN -13: 978-0-9944381-26.

6. Stupp, R.; Hegi, M.E.; Mason, W.P.; van Den Bert, M.J.; Taphoorn, M.J.; Janzer, R.C.; Ludwin, S.K.; Allgeier, A.; Fisher, B.; Belanger, K.; et al. European Organization for Research and Treatment of Cancer Brain Tumor and Radiotherapy Groups; National Cancer Institute of Canada Clinical Trials Group. Effects of Radiotherapy with Concomitant and Adjuvant Temozolomide versus Radiotherapy Alone on Survival in Glioblastoma in a Randomized Phase III Study: 5-Year Analysis of the EORTC-NCIC trial. Lancet Oncol. 2009, 10, 459-466. [CrossRef]

7. Zhang, J.; Stevens, M.F.; Bradshaw, T.D. Temozolomide: Mechanisms of Action, Repair and Resistance. Curr. Mol. Pharmacol. 2012, 5, 102-114. [CrossRef]

8. Tatar, Z.; Thivat, E.; Planchat, E.; Gimbergues, P.; Gadea, E.; Abria, C.; Durando, X. Temozolomide and Unusual Indications: Review of Literature. Cancer Treat Rev. 2013, 39, 125-135. [CrossRef]

9. Sengupta, S.; Marrian, J.; Frishman, C.; Sampath, P. Impact of Temozolomide on Immune Response during Malignant Glioma Chemotherapy. Clin. Dev. Immunol. 2012, 2012, 831090. [CrossRef]

10. Mendez, J.S.; Govindan, A.; Leong, J.; Gao, F.; Huang, J.; Campian, J.L. Association between Treatment-Related Lymphopenia and Overall Survival in Elderly Patients with Newly Diagnosed Glioblastoma. J. Neurooncol. 2016, 127, 329-335. [CrossRef]

11. Villano, J.L.; Letarte, N.; Yu, J.M.; Abdur, S. Hematologic Adverse Events Associated with Temozolomide. Cancer Chemother. Pharmacol. 2011, 69, 107-113. [CrossRef]

12. Gilbar, P.J.; Pokharel, K.; Mangos, H.M. Temozolomide-Induced Aplastic Anemia: Case Report and Review of the Literature. J. Oncol. Pharm. Pract. 2020, 27, 1275-1280. [CrossRef]

13. Alphandery, E. Glioblastoma Treatments: An Account of Recent Industrial Developments. Front. Pharmacol. 2018, 9, 879. [CrossRef]

14. Auffinger, B.; Spencer, D.; Pytel, P.; Ahmed, A.U.; Lesniak, M. The Role of Glioma Stem Cells in Chemotherapy Resistance and Glioblastoma Multiforme Recurrence. Expert Rev. Neurother. 2015, 15, 741-752. [CrossRef]

15. Bush, N.A.O.; Butowski, N. The Effect of Molecular Diagnostics on the Treatment of Glioma. Curr. Oncol. Rep. 2017, 19, 26. [CrossRef]

16. Ghoneum, A.; Abdulfattah, A.Y.; Warren, B.O.; Shu, J.; Said, N. Redox Homeostasis and Metabolism in Cancer: A Complex Mechanism and Potential Targeted Therapeutics. Int. J. Mol. Sci. 2020, 21, 3100. [CrossRef]

17. Cencioni, C.; Comunanza, V.; Middonti, E.; Valleriello, E.; Bussolino, F. The Role of Redox System in Metastasis Formation. Angiogenesis 2021, 24, 435-450. [CrossRef] [PubMed]

18. Reczek, C.R.; Chandel, N.S. The Two Faces of Reactive Oxygen Species in Cancer. Annu. Rev. Cancer Biol. 2017, 1, 79-98. [CrossRef]

19. Halliwell, B. Free Radicals and Antioxidants-Quo Vadis? Trends Pharmacol. Sci. 2011, 32, 125-130. [CrossRef]

20. Friedman, J. Why Is the Nervous System Vulnerable to Oxidative Stress. In Oxidative Stress and Free Radical Damage in Neurology; Gadoth, N., Gobel, H.H., Eds.; Humana Press: New York, NY, USA, 2011; pp. 19-27. ISBN 978-1-60327-514-9.

21. Wallace, D.C. Mitochondria in Cancer. Nat. Rev. Cancer 2012, 12, 685-698. [CrossRef] [PubMed]

22. Sabharwal, S.S.; Schumacker, P.T. Mitochondrial ROS in Cancer: Initiators, Amplifiers or an Achilles' Heel? Nat. Rev. Cancer 2014, 14, 709-721. [CrossRef] [PubMed]

23. Chen, K.; Lu, P.; Beeraka, N.M.; Sukocheva, O.A.; Madhunapantula, S.V.; Liu, J.; Sinelnikov, M.Y.; Nikolenko, V.N.; Bulygin, K.V.; Mikhaleva, L.M.; et al. Mitochondrial Mutations and Mitoepigenetics: Focus on Regulation of Oxidative Stress-Induced Responses in Breast Cancers. Semin. Cancer Biol. 2020. [CrossRef]

24. Trachootham, D.; Alexandre, J.; Huang, P. Targeting Cancer Cells by ROS-Mediated Mechanism: A Radical Therapeutic Approach? Nat. Rev. Drug Discov. 2009, 8, 579-591. [CrossRef]

25. Morry, J.; Ngamcherdtrakul, W.; Yantasee, W. Oxidative Stress in Cancer and Fibrosis: Opportunity for Therapeutic Intervention with Antioxidant Compounds, Enzymes, and Nanoparticles. Redox. Biol. 2017, 11, 240-253. [CrossRef]

26. Cheng, H.-L.; Lee, Y.-H.; Yuan, T.-M.; Chen, S.-W.; Chuen, P.-J. Update on a Tumor-Associated NADH Oxidase in Gastric Cancer Cell Growth. World J. Gastroenter. 2016, 22, 2900-2905. [CrossRef] 
27. Jiang, Z.; Gorenstein, N.M.; Morré, D.M.; Morré, D.J. Molecular Cloning and Characterization of a Candidate Human GrowthRelated and Time-Keeping Constitutive Cell Surface Hydroquinone (NADH) Oxidase. Biochemistry 2008, 47, 14028-14038. [CrossRef]

28. Salazar-Ramiro, A.; Ramirez-Ortega, D.; de la Cruz, V.P.; Hernandez-Pedro, N.Y.; Gonzalez-Esquivel, D.F.; Sotelo, J.; Pineda, B. Role of Redox Status in Development of Glioblastoma. Front. Immunol. 2016, 7, 156. [CrossRef]

29. Bakalova, R.; Zhelev, Z.; Aoki, I.; Saga, T. Tissue Redox Activity as a Hallmark of Carcinogenesis: From Early to Terminal Stages of Cancer. Clin. Cancer Res. 2013, 19, 2503-2517. [CrossRef]

30. Duraj, T.; Garcia-Romero, N.; Carrion-Navarro, J.; Madurga, R.; de Mendivil, A.O.; Prat-Acin, R.; Garcia-Canamaque, L.; AyusoSacido, A. Beyond the Warburg Effect: Oxidative and Glycolytic Phenotypes Coexist within the Metabolic Heterogeneity of Glioblastoma. Cells 2021, 10, 202. [CrossRef]

31. Kim, J.; Han, J.; Jang, Y.; Kim, S.J.; Lee, M.J.; Ryu, M.J.; Kweon, G.R.; Heo, J.Y. High-Capacity Glycolytic and Mitochondrial Oxidative Metabolism Mediate the Growth Ability of Glioblastoma. Int. J. Oncol. 2015, 47, 1009-1016. [CrossRef]

32. Gringuer, C.E.; Oliva, C.R. Bioenergetics Pathways and Therapeutic Resistance in Gliomas: Emerging Role of Mitochondria. Curr. Pharm. Des. 2011, 17, 2421-2427. [CrossRef]

33. Duman, C.; Yaqubi, K.; Hoffmann, A.; Acikgöz, A.A.; Korshunov, A.; Bendszus, M.; Herold-Mende, C.; Liu, H.K.; Alfonso, J. Acyl-CoA-Binding Protein Drives Glioblastoma Tumorigenesis by Sustaining Fatty Acid Oxidation. Cell Metab. 2019, 30, 274-289.e5. [CrossRef]

34. Sperry, J.; Condro, M.C.; Guo, L.; Braas, D.; Vanderveer-Harris, N.; Kim, K.K.O.; Pope, W.B.; Divakaruni, A.S.; Lai, A.; Christofk, H.; et al. Glioblastoma Utilizes Fatty Acids and Ketone Bodies for Growth Allowing Progression during Ketogenic Diet Therapy. iScience 2020, 23, 101453. [CrossRef]

35. Bacic, G.; Pavicevic, A.; Peyrot, F. In Vivo Evaluation of Different Alterations of Redox Status by Studying Pharmacokinetics of Nitroxides Using Magnetic Resonance Techniques. Redox. Biol. 2016, 8, 226. [CrossRef]

36. D'Autreaux, B.; Toledano, M.B. ROS as Signaling Molecules: Mechanisms That Generate Specificity in ROS Homeostasis. Nat. Rev. Mol. Cell Biol. 2007, 8, 813-824. [CrossRef]

37. Zhelev, Z.; Aoki, I.; Gadjeva, V.; Nikolova, B.; Bakalova, R.; Saga, T. Tissue Redox Activity as a Sensing Platform for Imaging of Cancer Based on Nitroxide Redox Cycle. Eur. J. Cancer 2013, 49, 1467-1478. [CrossRef]

38. Kroemer, G.; Pouyssegur, J. Tumor Cell Metabolism: Cancer's Achilles' Heel. Cancer Cell 2008, 13, 472-482. [CrossRef]

39. Torrisi, F.; Vicario, N.; Spitale, F.M.; Cammarata, F.P.; Minafra, L.; Salvatorelli, L.; Russo, G.; Cuttone, G.; Valable, S.; Gulino, R.; et al. The Role of Hypoxia and SRC Tyrosine Kinase in Glioblastoma Invasiveness and Radioresistance. Cancers 2020, 12, 2860. [CrossRef]

40. Jones, V.S.; Huang, R.-Y.; Chen, L.-P.; Chen, Z.-S.; Fu, L.; Huang, R.-P. Cytokines in Cancer Drug Resistance: Cues to New Therapeutic Strategies. Biochim. Biophys. Acta 2016, 1865, 255-265. [CrossRef]

41. Berraondo, P.; Sanmamed, M.F.; Ochoa, M.C.; Etxeberria, I.; Aznar, M.A.; Perez-Gracia, J.L.; Rodriguez-Ruiz, M.E.; Ponz-Sarvise, M.; Castanon, E.; Melero, I. Cytokines in Clinical Cancer Immunotherapy. Brit. J. Cancer 2019, 120, 6-15. [CrossRef]

42. Wang, J.; Xu, Z.; Wang, Z.; Du, G.; Lun, L. TGF-Beta Signaling in Cancer Radiotherapy. Cytokine 2021, 148, 155709. [CrossRef]

43. Magana-Maldonado, R.; Manoutcharian, K.; Hernandez-Pedro, N.Y.; Rangel-Lopez, E.; Perez-De la Cruz, V.; Rodriguez-Balderas, C.; Sotelo, J.; Pineda, B. Concomitant Treatment with Pertussis Toxin Plus Temozolomide Increases the Survival of Rats Bearing Intracerebral RG2 Glioma. J. Cancer Res. Clin. Oncol. 2014, 140, 291-301. [CrossRef] [PubMed]

44. Orozco-Morales, M.; Sanchez-Garcia, F.J.; Golan-Cancela, I.; Hernandez-Pedro, N.; Costoya, J.A.; de la Cruz, V.P.; Moreno-Jimenez S.; Sotelo, J.; Pineda, B. RB Mutation and RAS Overexpression Induce Resistance to NK Cell-Mediated Cytotoxicity in Glioma Cells. Cancer Cell Int. 2015, 15, 57. [CrossRef] [PubMed]

45. Yin, H.; Zhou, Y.; Wen, C.; Zhou, C.; Zhang, W.; Hu, X.; Wang, L.; You, C.; Shao, J. Curcumin Sensitizes Glioblastoma to Temozolomide by Simultaneously Generating ROS and Disrupting AKT/mTOR Signaling. Oncol. Rep. 2014, 32, 1610-1616. [CrossRef] [PubMed]

46. Bakalova, R.; Semkova, S.; Ivanova, D.; Zhelev, Z.; Miller, T.; Takeshima, T.; Shibata, S.; Lazarova, D.; Aoki, I.; Higashi, T. Selective Targeting of Cancerous Mitochondria and Suppression of Tumor Growth Using Redox-Active Treatment Adjuvant. Oxid. Med. Cell Longev. 2020, 2020, 6212935. [CrossRef] [PubMed]

47. Vafai, S.B.; Mevers, E.; Higgins, K.W.; Fomina, Y.; Zhang, J.; Mandinova, A.; Newman, D.; Shaw, S.Y.; Clardy, J.; Mootha, V.K. Natural Product Screening Reveals Naphthoquinone Complex I Bypass Factors. PLoS ONE 2016, 11, e0162686. [CrossRef] [PubMed]

48. Majamaa, K.; Rusanen, H.; Remes, A.; Hassinen, I.E. Metabolic interventions against complex I deficiency in MELAS syndrome. Mol. Cell Biochem. 1997, 174, 291-296. [CrossRef] [PubMed]

49. Chan, T.S.; Teng, S.; Wilson, J.X.; Galati, G.; Khan, S.; O’Brien, P.J. Coenzyme Q Cytoprotective Metabolisms for Mitochondrial Complex I Cytopathies Involves NAD(P)H: Quinone Oxidoreductase (NQO1). Free Radic. Res. 2002, 36, 421-427. [CrossRef] [PubMed]

50. Eleff, S.; Kennaway, N.G.; Buist, N.R.; Darley-Usmar, V.M.; Capaldi, R.A.; Bank, W.J.; Chance, B. 31P NMR Study of Improvement in Oxidative Phosphorylation by Vitamins K3 and C in a Patient with a Defect in Electron Transport at Complex III in Skeletal Muscle. Proc. Natl. Acad. Sci. USA 1984, 81, 3529-3533. [CrossRef] 
51. U.S. Department of Health and Human Services (FDA) Home Page. National Institutes of Health (Office of Dietary Supplements). Dietary Supplements for Primary Mitochondrial Disorders. 2020. Available online: https://ods.od.nih.gov/factsheets/ PrimaryMitochondrialDisorders-HealthProfessional/ (accessed on 5 January 2020).

52. Bakalova, R.; Zhelev, Z.; Miller, T.; Aoki, I.; Higashi, T. Vitamin C versus Cancer: Ascorbic Acid Radical and Impairment of Mitochondrial Respiration? Oxid. Med. Cell Longev. 2020, 2020, 1504048. [CrossRef]

53. Bakalova, R.; Zhelev, Z.; Miller, T.; Aoki, I.; Higashi, T. New Potential Biomarker for Stratification of Patients for Pharmacological Vitamin C in Adjuvant Settings of Cancer Therapy. Redox. Biol. 2020, 28, 101357. [CrossRef]

54. De Cabo, R.; Siendones, E.; Minor, R.; Navas, R. Cyb5R3: A Key Player in Aerobic Metabolism and Aging? Aging 2009, 2, 63-68. [CrossRef] [PubMed]

55. Nikiforova, A.B.; Saris, N.-E.L.; Kruglov, A.G. External Mitochondrial NADH-Dependent Reductase of Redox Cyclers: VDAC1 or Cyb5R3? Free Radic. Biol. Med. 2014, 74, 74-84. [CrossRef] [PubMed]

56. Ngo, B.; van Riper, J.; Cantley, L.C.; Yun, J. Targeting Cancer Vulnerabilities with High-Dose Vitamin C. Nat. Rev. Cancer 2019, 19, 271-282. [CrossRef] [PubMed]

57. Vita, M.F.; Nagachar, N.; Avramidis, D.; Delwar, Z.M.; Cruz, M.H.; Siden, A.; Paulsson, K.M.; Yakisich, J.S. Pankiller Effect of Prolonged Exposure to Menadione on Glioma Cells: Potentiation by Vitamin C. Investig. New Drugs 2011, 29, 1314-1320. [CrossRef]

58. Huang, J.; Agus, D.B.; Winfree, C.J.; Kiss, S.; Mack, W.; McTaggart, R.A.; Choudhri, T.F.; Kim, L.J.; Mocco, J.; Fox, W.D.; et al. Dehydroascorbic Acid, a Blood-Brain Barrier Transpotable form of Vitamin C.; Mediates Potent Cerebroprotection in Experimental Stroke. Proc. Natl. Acad. Sci. USA 2001, 98, 11720-11724. [CrossRef] [PubMed]

59. May, J.M. Vitamin C Transport and Its Role in the Central Nervous System. Subcell. Biochem. 2012, 56, 85-103. [CrossRef]

60. The Human Protein Atlas: ENOX2 Protein Expression Summary. Available online: http://www.proteinatlas.org/ENSG0000016 5675-ENOX2 (accessed on 2 November 2021).

61. Castellano, A.; Bailo, M.; Cicone, F.; Carideo, L.; Quartuccio, N.; Mortini, P.; Falini, A.; Cascini, G.L.; Minniti, G. Advanced Imaging Techniques for Radiotherapy Planning of Gliomas. Cancers 2021, 13, 1063. [CrossRef]

62. Song, J.; Kadaba, P.; Kravitz, A.; Hotmigo, A.; Friedman, J.; Belani, P.; Hadjipanayis, C.; Ellingston, B.M.; Nael, K. Multiparametric MRI for Early Identification of Therapeutic Response in Recurrent Glioblastoma Treated with Immune Checkpoint Inhibitors. Neurol. Oncol. 2020, 22, 1658-1666. [CrossRef]

63. Dikalov, S.; Harrison, D.G. Methods for Detection of Mitochondrial and Cellular Oxygen Species. Antioxid. Redox. Signal. 2014, 20, 372-382. [CrossRef]

64. Levraut, J.; Iwase, H.; Shao, Z.-H.; Vanden Hoek, T.L.; Schumacker, P.T. Cell Death during Ischemia: Relationship to Mitochondrial Depolarization and ROS Generation. Am. J. Physiol. Heart Circ. Physiol. 2003, 284, H549-H558. [CrossRef]

65. Semkova, S.; Zhelev, Z.; Miller, T.; Sugaya, K.; Aoki, I.; Higashi, T.; Bakalova, R. Menadione/Ascorbate Induces Overproduction of Mitochondrial Superoxide and Impairs Mitochondrial Function in Cancer: Comparative study on Cancer and Normal Cells of the Same Origin. Anticancer Res. 2020, 40, 1963-1972. [CrossRef] [PubMed]

66. Matsumoto, K.I.; Nakanishi, I.; Zhelev, Z.; Bakalova, R. Nitroxyl Radical as a Theranostic Contrast Agent in Magnetic Resonance Redox Imaging. Antioxid. Redox. Signal 2021. [CrossRef] [PubMed]

67. Verrax, J.; Vanbever, S.; Stockis, J.; Taper, H.; Calderon, P.B. Role of Glycolysis Inhibition and Poly(ADP Ribose)Polymerase Activation in Necrotic-Like Death Caused by Ascorbate/Menadione-Induced Oxidative Stress in K562 Human Chronic Myelogenous Leukemia Cells. Int. J. Cancer 2007, 120, 1192-1197. [CrossRef] [PubMed]

68. Beck, R.; Pedrosa, R.C.; Dejenas, N.; Glorieux, C.; Gallez, P.L.B.; Taper, H.; Eeckhoudt, S.; Knoops, L.; Calderon, P.B.; Verrax, J Ascorbate/Menadione-Induced Oxidative stress Kills Cancer Cells That Express Normal or Mutated Forms of the Oncogenic Protein Bcr-Abl. An In Vitro and In Vivo Mechanistic Study. Investig. New Drugs 2011, 29, 891-900. [CrossRef] [PubMed]

69. Ren, X.; Santhosh, S.M.; Coppo, L.; Ogata, F.T.; Lu, J.; Holmgren, A. The Combination of Ascorbate and Menadione Causes Cancer Cell Death by Oxidative Stress and Replicative Stress. Free Radic. Biol. Med. 2019, 134, 350-358. [CrossRef]

70. Greenwood, J.; Steinman, L.; Zamvil, S. Statin Therapy in Autoimmunity: From Protein Prenylation to Immunomodulation. Nat. Rev. Immunol. 2006, 6, 350-370. [CrossRef]

71. Ryszawy, D.; Pudelek, M.; Catapano, J.; Ciarach, M.; Setkowicz, Z.; Konduracka, E.; Madeja, Z.; Czyz, J. High Doses of Sodium Ascorbate Interfere with the Expansion of Glioblastoma Multiform Cells In Vitro and In Vivo. Life Sci. 2019, 232, 116657. [CrossRef]

72. Padayatty, S.; Sun, A.Y.; Chen, Q.; Epsey, M.G.; Drisko, J.; Levine, M. Vitamin C: Intravenous Use by Complementary and Alternative Medicine Practitioners and Adverse Effects. PLoS ONE 2010, 5, e11414. [CrossRef]

73. Carr, A.C.; Cook, J. Intravenous Vitamin C for Cancer Therapy-Identifying the Current Gaps in Our Knowledge. Front. Physiol. 2018, 9, 1182. [CrossRef]

74. Kim, K.; Bae, O.-N.; Koh, S.-H.; Kang, S.; Lim, K.-M.; Noh, J.-Y.; Shin, S.; Kim, I.; Chung, J.-H. High-Dose Vitamin C Injection to Cancer Patients May Promote Thrombosis through Procoagulant Activation of Erythrocytes. Toxicol. Sci. 2015, 147, 350-359. [CrossRef]

75. Grasso, C.; Fabre, M.-S.; Collis, S.V.; Castro, M.L.; Field, C.S.; Schleich, N.; McConnell, M.J.; Herst, P.M. Pharmacological Doses of Daily Ascorbate Protect Tumors from Radiation Damage after a Single Dose of Radiation in an Intracranial Mouse Glioma model. Front. Oncol. 2014, 4, 356. [CrossRef] 
76. Taper, H.S.; Roberfroid, M. Non-Toxic Sensitization of Cancer Chemotherapy by Combined Vitamin C and K3 Pre-Treatment in a Mouse Tumor Resistant to Oncovin. Anticancer Res. 1992, 12, 1651-1654.

77. Taper, H.S.; Keyeus, A.; Roberfroid, M. Potentiation of Radiotherapy by Nontoxic Pre-Treatment with Combined Vitamins C and K3 in Mice Bearing Solid Transplantable Tumor. Anticancer Res. 1996, 16, 499-503. [CrossRef] [PubMed]

78. Calderon, P.; Cadrobbi, J.; Marques, C.; Hong-Ngoc, N.; Jamison, J.M.; Summers, J.L.; Taper, H.S. Potential Therapeutic Application of the Association of Vitamins C and K3 in Cancer Treatment. Curr. Med. Chem. 2002, 9, 2271-2285. [CrossRef]

79. Taper, H.S.; Jamison, J.M.; Gilloteaux, J.; Summers, J.L.; Calderon, P.B. Inhibition of the Development of Metastases by Dietary Vitamin C: K3 Combination. Life Sci. 2004, 75, 955-967. [CrossRef] [PubMed]

80. Chen, M.F.; Yang, C.M.; Su, C.M.; Liao, J.W.; Hu, M.L. Inhibitory Effect of Vitamin C in Combination with Vitamin K3 on Tumor Growth and Metastasis of Lewis Lung Carcinoma Xenografted in C57Bl/6 Mice. Nutr. Cancer 2011, 63, 1036-1043. [CrossRef]

81. Du, J.; Gullen, J.J.; Buettner, G.R. Ascorbic Acid: Chemistry, Biology and the Treatment of Cancer. Biochim. Biophys. Acta 2012, 1826, 443-457. [CrossRef] [PubMed]

82. Criddle, D.N.; Gillies, S.; Baumgartner-Wilson, H.K.; Jaffar, M.; Chinje, E.C.; Passmore, S.; Chvanov, M.; Barrow, S.; Gerasimenko, O.V.; Tepikin, A.V.; et al. Menadione-Induced ROS Generation via Redox Cycling Promotes Apoptosis of Muruine Pancreatic Acinar Cells. J. Biol. Chem. 2006, 281, 40485-40492. [CrossRef] [PubMed]

83. Tielens, A.G.M.; Rotte, C.; van Hellemond, J.J.; Martin, W. Mitochondria as We Don't Know them. Trends Biol. Sci. 2002, 27, 564-572. [CrossRef]

84. Dubouchaud, H.; Walter, L.; Rigoulet, M.; Batandier, C. Mitochondrial NADH Redox Potential Impacts the ROS Production of Reverse Electron Transfer through Complex I. J. Bioenerg. Biomembr. 2018, 50, 367-377. [CrossRef]

85. Nakagawa, K.; Hirota, Y.; Sawada, N.; Yuge, N.; Watanabe, M.; Uchino, Y.; Okuda, N.; Shimomura, Y.; Suhara, Y.; Okano, T. Identification of UBIAD1 as a Novel Human Menaquinone-4 Biosynthetic Enzyme. Nature 2010, 468, 117-121. [CrossRef] [PubMed]

86. Nakagawa, K.; Fujiwara, K.; Nishimura, A.; Murakami, C.; Kawamoto, K.; Ichinose, C.; Kunitou, Y.; Suhara, Y.; Okano, T.; Hasegawa, H. UBIAD1 Plays an Essential Role in the Survival of Pancreatic Acinar Cells. Int. J. Mol. Sci. 2019, 20, 1971. [CrossRef] [PubMed]

87. The Human Protein Atlas: UBIAD1 Protein Expression Summary. Available online: http://www.proteinatlas.org/ENSG0000012 0942-UBUAD1 (accessed on 2 November 2021).

88. Li, H.; Qu, L.; Zhang, H.; Liu, J.; Zhang, X. A Comprehensive Transcriptomic Landscape of Cholangiosarcoma Based on Bioinformatics Analysis from Large Cohort of Patients. Sci. Rep. 2021, 11, 13713. [CrossRef] [PubMed]

89. Park, S.B.; Chung, C.K.; Gonzalez, E.; Yoo, C. Causal Inference Network of Genes Relates with Bone Metastasis of Breast Cancer and Osteoblasts Using Causal Bayesian Networks. J. Bone Metab. 2018, 25, 251-266. [CrossRef] [PubMed]

90. Xia, Y.; Wei, X.; Wu, S.; Wang, B.; Hong, L. Down-Regulation of TERE1/UBIAD1 Activated Ras-MAPK Signalling and Induced Cell Proliferation. Cell Biol. Int. Rep. 2010, 17, e00005. [CrossRef]

91. Mao, H.; LeBrun, D.G.; Yang, J.; Zhu, V.F.; Li, M. Deregulated Signaling Pathways in Glioblastoma Multiform: Mechanisms and Therapeutic Targets. Cancer Investig. 2012, 30, 48-56. [CrossRef]

92. Frederiks, W.J.; Sepulveda, J.; Lai, P.; Tomaszewski, J.E.; Lin, M.-F.; McGarvey, T.; Rauscher, F.J.; Malkovicz, S.B. The Tumor Suppressor TERE1 (UBIAD1) Prenyltransferase Regulates the Elevated Cholesterol Phenotype in Castration Resistant Prostate Cancer by Controlling a Program of Ligand Dependent SXR Target Genes. Oncotarget 2013, 4, 1075-1092. [CrossRef]

93. Liu, S.; Guo, W.; Han, X.; Dai, W.; Diao, Z.; Liu, W. Role of UBIAD1 in Intracellular Cholesterol Metabolism and Vascular Cell Calcification. PLoS ONE 2016, 11, e0149639. [CrossRef] [PubMed]

94. Chong, T.L.; Emily, E.L.; Cimmino, L. Reprogramming the Epigemome with Vitamin C. Front. Cell Dev. Biol. $2019,7,128$. [CrossRef]

95. Weller, M.; Stupp, R.; Reifenberger, G.; Brandes, A.A.; van den Bent, M.J.; Wick, W.; Hegi, M.E. MGMT Promoter Methylation in Malignant Gliomas: Ready for Personalized Medicine? Nat. Rev. Neurol. 2010, 6, 39-51. [CrossRef]

96. Fresnais, M.; Turcan, S.; Theile, D.; Ungermann, J.; Abou Zeed, Y.; Lindner, J.R.; Breitkopf, M.; Burhenne, J.; Haefeli, W.E.; Longuespee, R. Approaching Sites of Action of Temozolomide for Pharmacological and Clinical Studies in Glioblastoma. Biomedicines 2022, 10, 1. [CrossRef]

97. Hsieh, P.-F.; Chueh, P.J.; Liu, P.-F.; Liao, J.-W.; Hsieh, M.-K. Immune Response Evoked by Tumor-Associated NADH Oxidase (tNOX) Confers Potential Inhibitory Effect on Lung Carcinoma in a Mouse Model. Am. J. Cancer Res. 2019, 9, 740-751. [PubMed]

98. Yang, L.; Pang, Y.; Moses, H.L. TGB-b and Immune Cells: An Important Regulatory Axis in the Tumor Microenvironment and Progression. Trends Immunol. 2010, 31, 220-227. [CrossRef]

99. Travis, M.A.; Sheppard, D. TGF-b Activation and Function in Immunity. Annu. Rev. Immunol. 2014, 32, 51-82. [CrossRef]

100. Park, B.V.; Freeman, Z.T.; Ghasemzadeh, A.; Chattergoon, M.A.; Rutebenberwa, A.; Steigner, J.; Winter, M.E.; Huynh, T.V.; Sebald, S.M.; Lee, S.-J.; et al. TGF-b1-Mediated Smad3 Enhances PD-1 Expression on Antigen-Specific T Cells in Cancer. Cancer Discov. 2016, 6, 1366-1381. [CrossRef] [PubMed]

101. Ryan, D.G.; Murphy, M.P.; Frezza, C.; Prag, H.A.; Chouchani, E.T.; O’Neill, L.A.; Mills, E.L. Coupling Krebs Cycle Metabolites to Signaling in Immunity and Cancer. Nat. Metab. 2019, 1, 16-33. [CrossRef]

102. Hostetler, B.; Weston, N.; Kim, C.; Morre, D.M.; Morre, D.J. Cancer Site-Specific Isoforms of ENOX2 (tNOX): A Cancer-Specific Cell Surface Oxidase. Clin. Proteom. 2009, 5, 46-51. [CrossRef] 
103. Chen, H.Y.; Cheng, H.L.; Lee, Y.H.; Yuan, T.M.; Chen, S.W.; Lin, Y.Y.; Chueh, P.J. Tumor-Associated NADH Oxidase (tNOX)$\mathrm{NAD}^{+}$-Sirtuin 1 Axis Contributes to Oxaliplatin-Induced Apoptosis of Gastric Cancer Cells. Oncotarget 2017, 8, 15338-15348. [CrossRef]

104. Chen, H.Y.; Islam, A.; Yuan, T.M.; Chen, S.W.; Liu, P.F.; Chuen, P.J. Regulation of tNOX Expression through the ROS-p53-POU3F2 Axis Contributes to Cellular Responses against Oxaliplatin in Human Colon Cancer Cells. J. Exp. Clin. Cancer Res. 2018, $37,161$. [CrossRef]

105. Lee, Y.H.; Chen, H.Y.; Su, L.J.; Chueh, P.J. Sirtuin 1 (SIRT1) Deacetylase Activity and NAD ${ }^{+}$NADH Ratio Are Imperative for Capsaicin-Mediated Programmed Cell Death. J. Agric. Food Chem. 2015, 63, 7361-7367. [CrossRef]

106. Islam, A.; Hsieh, P.-F.; Chou, J.-C.; Liao, J.-W.; Hsieh, M.-K.; Chuen, P.J. Capsaicin Exerts Therapeutic Effects by Targeting tNOX-SIRT1 Axis and Augmenting ROS-Dependent Cytotoxic Autophagy in Melanoma Cancer Cells. Am. J. Cancer Res. 2021, 11, 4199-4219. [PubMed]

107. Su, Y.C.; Lin, Y.H.; Zeng, Z.M.; Shao, K.N.; Chueh, P.J. Chemotherapeutic Agents Enhance Cell Migration and Epithelial-toMesenchymal Transition through Transient Up-Regulation of tNOX (ENOX2) Protein. Biochim. Biophys. Acta 2012, 1820, $1744-1752$. [CrossRef] [PubMed]

108. Liu, N.C.; Hsieh, P.F.; Hsieh, M.K.; Zeng, Z.M.; Cheng, H.L.; Liao, J.W.; Chueh, P.J. Capsaicin-Mediated tNOX (ENOX2) UpRegulation Enhances Cell Proliferation and Migration In Vitro and In Vivo. J. Agric. Food Chem. 2012, 60, 2758-2765. [CrossRef] [PubMed]

109. Gunderson, A.J.; Yamazaki, T.; McCarty, K.; Fox, N.; Phillips, M.; Alice, A.; Blair, T.; Whiteford, M.; O’Brien, D.; Ahmad, R.; et al. TGF-b Suppresses CD8 ${ }^{+}$T Cell Expression of CXCR3 and Tumor Trafficking. Nat. Commun. 2020, 11, 1749. [CrossRef]

110. Neganova, M.; Liu, J.; Aleksandrova, Y.; Kluchkov, S.; Fan, R. Therapeutic Influence on Important Targets Associated with Chronic Inflammation and Oxidative Stress in Cancer Treatment. Cancers 2021, 13, 6062. [CrossRef]

111. Lan, T.; Chen, L.; Wei, X. Inflammatory Cytokines in Cancer: Comprehensive Understanding and Clinical Progress in Gene Therapy. Cells 2021, 10, 100. [CrossRef] [PubMed]

112. Kundu, J.K.; Surh, Y.-J. Emerging Avenues Linking Inflammation and Cancer. Free Radic. Biol. Med. 2012, 52, 2013-2037. [CrossRef]

113. Gregg, D.; de Carvalho, D.D.; Kavacic, H. Integrins and Coagulation: A Role for ROS/Redox Signaling? Antioxid. Redox. Signal 2004, 6, 757-764. [CrossRef]

114. Malenica, I.; Adam, J.; Corgnac, S.; Mezquita, L.; Auclin, E.; Damei, I.; Grynszpan, L.; Gros, G.; de Montpreville, V.; Planchard, D.; et al. Integrin-AV-Mediated Activation of TGF-b Regulates Anti-Tumor CD8 T Cell Immunity and Response to PD-1 Blockade. Nat. Commun. 2021, 12, 5209. [CrossRef]

115. De Bleser, P.J.; Xu, G.; Rombouts, K.; Rogiers, V.; Geerts, A. Glutathione Levels Discriminate between Oxidative Stress and Transforming Growth Factor-B Signaling in Activated Rat Hepatic Stellate Cells. J. Biol. Chem. 1999, 274, 33881-33887. [CrossRef] [PubMed]

116. Dahmani, A.; Selisle, J.-S. TGF-B in T Cell Biology: Implications for Cancer Immunotherapy. Cancers 2018, 10, 194. [CrossRef] [PubMed]

117. Marin-Acevedo, J.A.; Kimbrough, E.O.; Lou, Y. Next Generation of Immune Checkpoint Inhibitors and Beyond. J. Hematol. Oncol. 2021, 14, 45. [CrossRef] [PubMed]

118. Khasraw, M.; Reardon, D.A.; Weller, M.; Sampson, J.H. PD-1 Inhibitors: Do They Have a Future in the Treatment of Glioblastoma? Clin. Cancer Res. 2020, 26, 5287-5296. [CrossRef] [PubMed]

119. Jiang, S.; Yan, W. Succinate in the Cancer-Immune Cycle. Cancer Lett. 2017, 390, 45-47. [CrossRef]

120. Martinez-Reyes, I.; Chandel, N.S. Mitochondrial TCA Cycle Metabolites Control Physiology and Disease. Nat. Commun. 2020, 11, 102. [CrossRef]

121. Checker, R.; Sharma, D.; Sandur, S.K.; Khan, N.M.; Patwardhan, R.S.; Kohli, V.; Sainis, K.B. Vitamin K3 Suppressed Inflammatory and Immune Responses in a Redox-Dependent Manner. Free Radic. Res. 2011, 45, 975-985. [CrossRef] [PubMed]

122. Zheng, X.; Hou, Y.; He, H.; Chen, Y.; Zhou, R.; Wang, X.; Gong, T.; Jiang, W. Synthetic Vitamin K Analogs Inhibit Inflammation by Targeting the NLRP3 Inflammasome. Cell Mol. Immunol. 2021, 18, 2422-2430. [CrossRef]

123. Zitvogel, L.; Pietrocola, F.; Kroemer, G. Nutrition, Inflammation, and Cancer. Nat. Immunol. 2017, 18, 843-850. [CrossRef]

124. Eilaghi, A.; Yeung, T.; d’Esterre, C.; Bauman, G.; Yartsev, S.; Easaw, J.; Fainardi, E.; Lee, T.-Y.; Frayne, R. Quantitative Perfusion and Permeability Biomarkers in Brain Cancer from Tomographic CT and MR Images. Biomark. Cancer 2016, 8 (Suppl. 2), 47-59. [CrossRef]

125. Van Dijken, B.R.J.; Van Laar, P.J.; Smits, M.; Dankbaar, J.W.; Enting, R.H.; van der Hoom, A. Perfusion MRI in Treatment Evaluation of Glioblastomas: Clinical Relevance of Current and Future Techniques. J. Magn. Reson. Imaging 2019, 49, 11-22. [CrossRef]

126. Lah, T.T.; Novak, M.; Breznik, B. Brain Malignancies: Glioblastoma and Brain Metastasis. Semin. Cancer Biol. 2020, 60, $262-273$. [CrossRef] [PubMed]

127. Couto, M.; Coelho-Santos, V.; Santos, L.; Fontes-Ribeiro, C.; Silva, A.P.; Gomes, C.M.F. The Interplay between Glioblastoma and Microglial Cells Leads to Endothelial Cell Monolayer Dysfunction via the Interleukin-6-Induced JAK2/STAT3 Pathway. J. Cell Physiol. 2019, 234, 19750-19760. [CrossRef] [PubMed]

128. Sugahara, T.; Korogi, Y.; Kochi, M.; Ikushima, I.; Shigematu, Y.; Hirai, T.; Okuda, T.; Liang, L.; Ge, Y.; Komohara, Y.; et al. Usefulness of Diffusion-Weighted MRI with Echo-Planar Technique in the Evaluation of Cellularity in Glioma. Magn. Reson. Imaging 1999, 9, 53-60. [CrossRef] 
129. Tourell, M.C.; Shokoohmand, A.; Landgraf, M.; Holzapfel, N.P.; Poh, P.S.P.; Loessner, D.; Momot, K.I. The Distribution of the Apparent Diffusion Coefficient as an Indicator of the Response to Chemotherapeutics in Ovarian Tumor Xenografts. Sci. Rep. 2017, 7, 42905. [CrossRef]

130. Surov, A.; Meyer, H.J.; Wienke, A. Correlation between Apparent Diffusion Coefficient (ADC) and Cellularity Is Different in Several Tumors: A Meta-Analysis. Oncotarget 2017, 8, 59492-59499. [CrossRef] [PubMed]

131. Fliedner, F.P.; Engel, T.B.; El-Ali, H.H.; Hansen, A.E. Diffusion Weighted Magnetic Resonance Imaging (DW-MRI) as a NonInvasive, Tissue Cellularity Marker to Monitor Cancer Treatment Response. BMC Cancer 2020, 20, 134. [CrossRef]

132. Surov, A.; Meyer, H.J.; Wienke, A. Apparent Diffusion Coefficient for Distinguishing between Malignant and Benign Lesions in the Head and Neck Region: A Systematic Review and Meta-Analysis. Front. Oncol. 2019, 9, 1362. [CrossRef]

133. Gilloteaux, J.; Jamison, J.M.; Arnold, D.; Taper, H.S.; Summers, J.L. Ultrastructural Aspects of Autoschizis: A New Cancer Cell Death Induced by the Synergistic Action of Ascorbate/Menadione on Human Bladder Carcinoma Cells. Ultrastruct. Pathol. 2001, 25, 183-192. [CrossRef]

134. Nguyen, C.; Pandey, S. Exploiting Mitochondrial Vulnerabilities to Trigger Apoptosis Selectively in Cancer Cells. Cancers 2019, 11, 916. [CrossRef] [PubMed] 